\title{
The Diversity of Intermediate Filaments in Astrocytes
}

\author{
Maja Potokar ${ }^{1,2}$, Mitsuhiro Morita ${ }^{3}$, Gerhard Wiche ${ }^{2,4}$ (i) and Jernej Jorgačevski ${ }^{1,2, *(1)}$ \\ 1 Laboratory of Neuroendocrinology - Molecular Cell Physiology, Institute of Pathophysiology, Faculty of \\ Medicine, University of Ljubljana, 1000 Ljubljana, Slovenia; maja.potokar@mf.uni-lj.si \\ 2 Celica BIOMEDICAL, 1000 Ljubljana, Slovenia; gerhard.wiche@univie.ac.at \\ 3 Department of Biology, Kobe University Graduate School of Science, Kobe 657-8501, Japan; \\ mmorita@boar.kobe-u.ac.jp \\ 4 Department of Biochemistry and Cell Biology, Max F. Perutz Laboratories, University of Vienna, \\ 1030 Vienna, Austria \\ * Correspondence: jernej.jorgacevski@mf.uni-lj.si; Tel.: +386-(1)-543-7081
}

Received: 4 June 2020; Accepted: 1 July 2020; Published: 2 July 2020

\begin{abstract}
Despite the remarkable complexity of the individual neuron and of neuronal circuits, it has been clear for quite a while that, in order to understand the functioning of the brain, the contribution of other cell types in the brain have to be accounted for. Among glial cells, astrocytes have multiple roles in orchestrating neuronal functions. Their communication with neurons by exchanging signaling molecules and removing molecules from extracellular space takes place at several levels and is governed by different cellular processes, supported by multiple cellular structures, including the cytoskeleton. Intermediate filaments in astrocytes are emerging as important integrators of cellular processes. Astrocytes express five types of intermediate filaments: glial fibrillary acidic protein (GFAP); vimentin; nestin; synemin; lamins. Variability, interactions with different cellular structures and the particular roles of individual intermediate filaments in astrocytes have been studied extensively in the case of GFAP and vimentin, but far less attention has been given to nestin, synemin and lamins. Similarly, the interplay between different types of cytoskeleton and the interaction between the cytoskeleton and membranous structures, which is mediated by cytolinker proteins, are understudied in astrocytes. The present review summarizes the basic properties of astrocytic intermediate filaments and of other cytoskeletal macromolecules, such as cytolinker proteins, and describes the current knowledge of their roles in normal physiological and pathological conditions.
\end{abstract}

Keywords: astrocytes; intermediate filaments; GFAP; vimentin; nestin; synemin; plectin; cytolinker proteins; reactive gliosis

\section{Introduction}

The first observation of neuroglia, made by Rudolf Virchow in 1858, was rather dubious. He described it as a substance with a somewhat static role of holding together and giving form to the nervous parts. In the period of silver staining, pioneered by Camillo Golgi, glia was first recognized to possess proper cell characteristics and, before the turn of the 19th century, the most numerous cells of glia were named astrocytes [1]. The interest of the scientific community in astrocytes then slowed down for nearly a century, mainly because neurons were recognized as the single independent anatomical and physiological unit of the nervous system, capable of efficient communication over long distances [2]. Only when it became clear that astrocytes possess a specific form of calcium excitability, and that they are (in addition to microglia) implicated in inflammatory responses [3], did astrocytes recapture research attention in the scientific community [4-6]. Astrocytes were shown to be capable of propagating waves of calcium between the cytosols of neighboring cells, which, considering their abundance in the brain, was proposed to lead to an "extraneuronal pathway for rapid long-distance 
signal transmission within the central nervous system (CNS)" [5]. At the same time, Cornell-Bell and coworkers [5] proposed that calcium dynamics in astrocytes may influence neuronal activity in a bi-directional fashion. This new paradigm aroused the interest of several independent groups, which before long confirmed that astrocytes can respond to glutamatergic synaptic transmission [7] and vice versa-that calcium waves, initiated in astrocytes, can result in the modulation of neuronal activity $[8,9]$. Hence, the term tripartite synapse was coined, whereby astrocytes were recognized as partners of neurons that respond to synaptic activity and regulate synaptic transmission [10]. Research carried out soon after the identification of bi-directional communication between astrocytes and neurons suggested that one of the distinct pathways of astrocyte communication involves regulated exocytosis (i.e., the release of "gliotransmitters" by astrocytes) [9]. A quintessential step of exocytosis in astrocytes is vesicular transport [11], which precedes vesicle fusion and is governed not only by commonly associated cytoskeletal elements (microtubules and actin filaments) but also by intermediate filaments (IFs) $[12,13]$. Of course, the involvement of IFs in vesicular transport is distinct, because they are apolar, which prevents them being used as tracks, unlike microtubules and actin meshwork, which are utilized by specialized motor proteins that convert chemical energy into mechanical work [14].

Historically, the research on IFs in astrocytes did not start with vesicular transport. The first visualization of IFs overlaps to some extent with the discovery of astrocytes, because Golgi's silver staining and its variations (notably Ramón and Cajal's own astrocyte-specific gold sublimate stain) target IFs among other cellular components [15]. Throughout the 20th century, a series of IF-related discoveries were made, mainly in the field of keratins, which coincided with the development of new methodologies and methods for the preparation of biological specimens (for an interesting review, see [16]). One of the greatest challenges in the early stages of IF research was the classification of different IF members in a common family. In contrast to highly conserved actin filaments and microtubules, IFs derive from approximately 70 different genes, and the diversity of expressed proteins is further increased by multiple splice variants of the same genes $[17,18]$. In addition, although IFs are still commonly used as cell type markers, many cell types express more than one type of IF, and the expression of individual IFs frequently also depends on the physiological state of the cell. For example, glial fibrillary acidic protein (GFAP) was considered to be a reliable marker of glial and astrocyte cell identity, yet current investigations have shown that GFAP is not an absolute marker of all non-reactive astrocytes because it is often not immunohistochemically detectable in astrocytes of healthy CNS tissue remote from CNS lesions [19]. Be that as it may, starting with the molecular characterization of $\alpha$-keratin in the early 1960s [20], ultrastructural analysis provided the first repeating pattern of fibers in different cell types; the average diameter of these fibers was measured at $10 \mathrm{~nm}$ [21-23]. This diameter is intermediate between that of microfilaments $(\sim 6 \mathrm{~nm})$ and microtubules $(\sim 24 \mathrm{~nm})$, which earned this group of filaments its name [23]. At the time, various IFs were given a number of different names and were frequently misidentified as microtubules [16]. In the 1970s and 1980s, several types of IFs had been isolated, owing to their conspicuous insolubility, which, combined with the development of molecular tools (including antibodies against individual IFs), facilitated the research on IF structure and intracellular localization [24-27]. Systematic analysis of the molecular organization of IFs revealed a typical tripartite structure, a globular $\mathrm{N}$ terminus (head) and $\mathrm{C}$ terminus, connected by a central $\alpha$-helical domain (the "rod") with a number of coiled-coil segments of conserved size [28]. Based on their amino acid sequence, protein structure and tissue-specific expression patterns, IFs were initially classified into five groups [29]; however, after the discovery of nestin, Group VI was added to the classification [30]. It was in 1971 that the first IF was identified in astrocytes. A well-known characteristic of astrocytes, i.e., their ability to form fibers under a variety of pathological conditions (fibrous gliosis), together with the acidic properties of the new isolated protein, were merged into the name glial fibrillary acidic protein [3]. In the years that followed, astrocytes were also shown to express vimentin, nestin, synemin and lamins, which intricately interact with each other as well as with other filament types. 


\section{Glial Fibrillary Acidic Protein and Vimentin}

\subsection{Structure and Expression of Glial Fibrillary Acidic Protein in Astrocytes}

GFAP forms characteristic fibres in astrocytes and was first isolated from sections of elder human brain that showed severe fibrous gliosis [3]. A substantial amount of research in the five decades since the discovery of GFAP has resulted in extensive knowledge of its properties and functions. GFAP is the principal astrocyte IF protein and is widely used as a diagnostic marker for astrocyte-derived human neoplasms and as a marker of astrocytes and astrocyte precursors [31,32]. Despite high specificity for astrocytes, GFAP is also expressed by neural stem cells and, albeit rarely, in non-glial cells [33-35]. Therefore, it was suggested that the proper detection of astrocytes should combine the identification of different astrocyte markers, such as ALDH1L1 [36]. Ten splicing variants of GFAP mRNA have been described so far, as shown in Table 1 (reviewed in [18,37]), ranging in approximate size between 38 and $50 \mathrm{kDa}$ [38]. GFAP is a Type III IF [39] and, similar to other type III IFs, is able to form filaments without a binding partner, although such homopolymers show atypical organization and tend to cluster, as observed in mouse CNS [40,41].

Table 1. Astrocytes express five types of IF proteins. GFAP and vimentin isoforms are splice variants of a single gene and lamin isoforms are encoded by different genes.

\begin{tabular}{|c|c|c|c|c|}
\hline IF Protein & Type & Isoforms in Astrocytes & Size (kDa) & Function in Astrocytes \\
\hline $\begin{array}{l}\text { Glial fibrillary acidic } \\
\text { protein (GFAP) }\end{array}$ & III & $\begin{array}{c}\alpha, \beta, \gamma, \delta(\varepsilon), \xi, \kappa, \Delta 135, \Delta 164, \Delta \text { exon6, } \\
\Delta \text { exon7 }[18,37]\end{array}$ & $38-50[38]$ & $\begin{array}{c}\text { Resistance to mechanical stress, cell } \\
\text { migration and motility, mitosis, } \\
\text { myelinization, maintenance and } \\
\text { permeability of the blood-brain barrier, } \\
\text { neurogenesis, chaperone-mediated } \\
\text { autophagy, vesicle mobility, glial scar } \\
\text { formation, response to hypoosmotic stress } \\
{[12,13,32,37,41-45]}\end{array}$ \\
\hline Nestin & VI & No splice variants reported in astrocytes & $240[50]$ & $\begin{array}{l}\text { Shape of protrusions, neurogenesis, } \\
\text { cell motility }[44,51]\end{array}$ \\
\hline
\end{tabular}

The aberrant appearance of IFs is otherwise typical for a range of epithelial, muscle and neuronal disorders, including gliomas and Alexander disease. GFAP is a standard marker of more differentiated astrocytoma (i.e., a type of glioma with astrocyte features). However, a thorough analysis of the reports focusing on GFAP expression in patients with astrocytoma did not confirm the correlation between general GFAP expression and astrocytoma malignancy [60]. Instead, van Bodegraven and coworkers proposed that astrocytoma malignancy is well reflected by the ratio of GFAP isoforms GFAP $\delta$ and GFAP $\alpha$ (a canonical GFAP isoform), which could improve the accuracy of assessing the differentiation state of this type of glioma [60]. GFAPס is an endogenous GFAP isoform and is typically expressed at low levels $(\sim 10 \%)$ [61]. In astrocytoma cells, the silencing of the GFAP $\alpha$ isoform increased the GFAP $/ \mathrm{GFAP} \alpha$ transcript level ratio, as well as the expression of the extracellular matrix protein laminin. Simultaneously, the downregulation of plectin mRNA and protein levels was observed, which together resulted in the decreased mobility of cells [62]. Natural occurrence of GFAP isoforms other than GFAP $\alpha$, such as GFAP $\delta$, implies that GFAP filaments can accommodate a small proportion of other residues, including those with aggregation-prone mutations [61]. Alexander disease is intrinsically linked to heterozygous mutations of GFAP gene [41,63]. Rosenthal fibers are composed of numerous proteins, including several IFs, such as GFAP, vimentin, synemin and the cytolinker, 
plectin [64-66]. Vimentin and nestin are GFAP co-polymerization partners that form heteropolymers in astrocytes [41,67], whereas GFAP merely associates with synemin [68].

Similar to other IFs, GFAP also shows a developmental pattern of expression. Its expression in rat cortex gradually increases from embryonal to adult stage, showing an inverse trend compared with other IFs (vimentin, nestin, synemin) [69]. The expression of GFAP in astrocytes is further enhanced in pathological conditions, such as neurotrauma and neurodegenerative disorders [32], as reviewed in Section 2.1. So far, the function of GFAP has been linked to a variety of processes implicated in the signaling and structural properties of astrocytes, ranging from resistance to mechanical stress, mitosis, the anchoring of transporters, the motility of cells, the mobility of vesicles and resistance to oxidative and electrophilic stress, as shown in Table 1 [13,32,37,42,43,70]. Functional studies of GFAP in astrocytes are in many cases linked and interpreted in combination with its polymerizing partner vimentin.

\subsection{Structure and Expression of Vimentin in Astrocytes}

Vimentin is the most common co-polymerization partner of GFAP and is considered as the principal IF, at least in adult astrocytes [71]. The discovery of vimentin, which is also a Type III IF, dates back to 1978, when it was isolated from a murine embryonic fibroblast cell line, as shown in Table 1 [46]. Reports of astrocytes positive for vimentin followed soon after [72-75].

Vimentin synthesis begins early during mammalian embryogenesis, and assembled vimentin filaments were observed somewhere around days E7-E11 of mouse embryogenesis, depending on the cell type [75]. Vimentin expression in astrocytes decreases with development and may completely cease in adult CNS or remain expressed at detectable levels. For example, Bergmann glia, Müller glia, radial glia and a subset of cortical astrocytes continue to express vimentin (together with GFAP) in the adult stage, suggesting a functional role for vimentin in these cells $[69,75,76]$. Generally, the tendency of vimentin expression to cease is reversed in different neurological conditions [48]; its increased expression in reactive astrocytes in conjunction with GFAP is reviewed in Section 2.1.

Vimentin shares high sequence homology throughout vertebrates [77]. Similar to GFAP, it has the ability to assemble into homopolymers or form heteropolymers with its co-polymerization partners-these are GFAP, nestin, and synemin in the case of astrocytes [41,68]. Vimentin filaments are highly dynamic structures. Similar to other IFs, their structure and assembly is regulated by phosphorylation [41,78-80], influencing several cellular functions. As demonstrated in different cell types, vimentin acts as an organizer of numerous crucial proteins involved in attachment, migration and cell signaling [77]. Similarly, in astrocytes, vimentin has been demonstrated to influence mechanical stability and the morphology of cells, cell motility, vesicle trafficking, the guiding of progenitors along the glial scar, cell division and signaling where phosphorylation reactions play a significant part, as shown in Table $1[13,41,44,49,81]$. Phosphorylation also regulates the interactions of vimentin with 14-3-3 proteins, as demonstrated by the application of the phosphatase inhibitor calyculin A [82]. The 14-3-3 dimeric phosphoserine/threonine-binding molecules are found in all eukaryotic organisms and participate in developmental processes, signal transduction, checkpoint controls, nutrient sensing, and cell survival pathways [83]. The sequestering of 14-3-3 molecules by phosphorylated vimentin is predicted to limit its availability to other target proteins, thereby affecting intracellular signaling processes that require pathways linked to 14-3-3 [82]. The phosphorylation-induced depolymerization of vimentin filaments by calyculin A in astrocytes was demonstrated to severely reduce vesicle trafficking [13]. Similarly, the absence of vimentin expression in astrocytes devoid of IFs (GFAP ${ }^{-/-} \mathrm{Vim}^{-/}$astrocytes) attenuates the displacement of vesicles, supporting the hypothesis that IFs are required for long-range directional vesicle mobility by acting as a three-dimensional lattice [13]. A hypothesis has been proposed that the upregulation of IFs in pathological states may alter the function of astrocytes by deregulating the vesicle trafficking of vesicles carrying peptide, transporters and vesicles in endosomal/lysosomal pathways $[11,12,43]$. Altered vesicle trafficking is also related to the redistribution of IFs in conditions that are typically present in such states, as shown in Figure 1. 

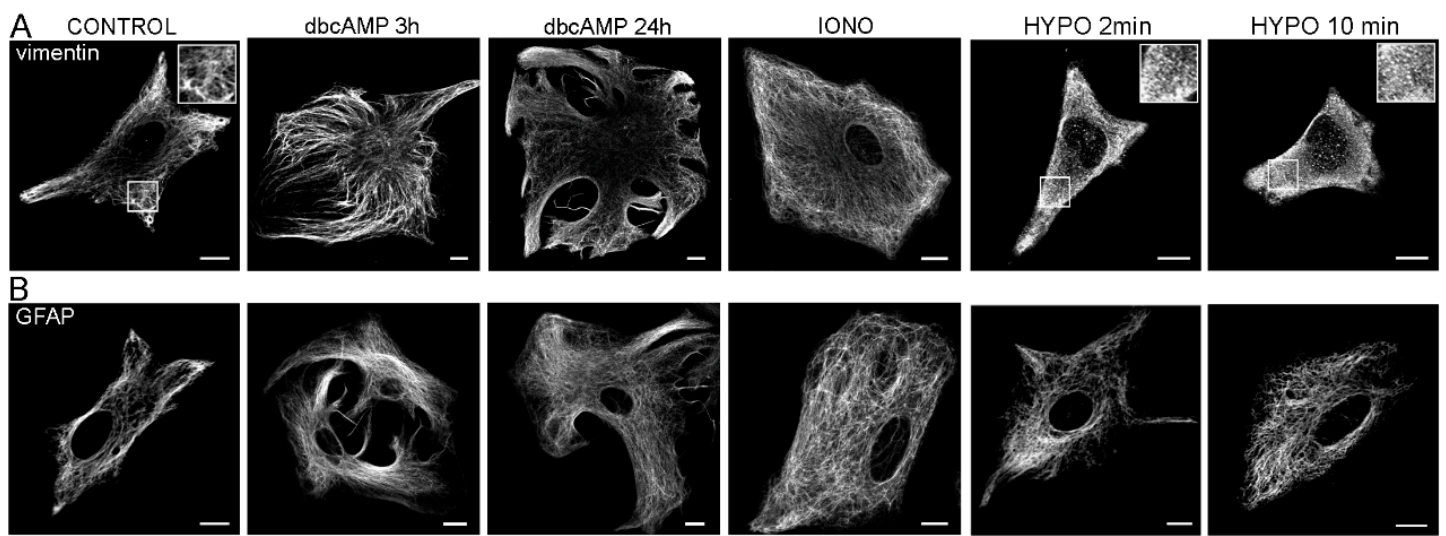

Figure 1. Cellular distribution of GFAP and vimentin cytoskeleton in primary rat astrocytes in normal conditions and in conditions that are typically present in pathological states. Astrocytes treated with dbcAMP (N 6,2'-O -dibutyryladenosine 3' :5' cyclic monophosphate), a membrane-permeable analogue of cAMP, mimic general reactive gliosis. Hypotonic stimulation, on the other hand, leads readily to astrocyte swelling, which is a part of the cytotoxic or cellular edema response. Changes in intracellular arrangement of vimentin (A) and GFAP (B) filaments are evident in reactive astrocytes (after cAMP stimulation) and after hypotonic stimulation (HYPO), as revealed by immunolabeling. Note also the stellated morphology of astrocytes after the increase in cAMP. Hypotonic treatment triggered depolymerization of vimentin filaments—selected areas (white squares) are magnified $(2 \times)$ —in insets Bars: $10 \mu \mathrm{m}$. Modified with permission from [84] (Regulation of AQP4 Surface Expression via Vesicle Mobility in Astrocytes, GLIA, Copyright@ 2013 Wiley Periodicals, Inc., (Hoboken, NJ, USA)).

\subsection{Reactive Gliosis}

As a consequence of any insult to the CNS (e.g., trauma, stroke or ischaemia), astrocytes respond by changing their phenotype and gene expression. Hallmarks of this response, which is referred to as reactive gliosis (also astrogliosis), are hypertrophy, proliferation and metabolic changes, which have a multifaceted impact on pathological processes. The progression of neurodegenerative diseases, including Alzheimer's disease and amyotrophic lateral sclerosis, is associated with the accumulation of reactive astrocytes producing toxic substances, such as reactive oxygen species and matrix metalloproteases $[85,86]$, whereas recovery from brain injuries is exacerbated by the ablation of reactive astrocytes $[87,88]$. The production of extracellular matrix and factors promoting synapse formation or pruning by reactive astrocytes is a determinant of prognosis for neuropathological conditions, including post-traumatic epilepsy $[89,90]$.

Reactive astrocytes are derived not only from astrocytes but apparently also from non-astrocytic cells, such as neural stem cells or oligodendrocyte progenitor cells [91-93]. However, the significance of reactive astrocytes derived from neuron-glial antigen 2 (NG2) expressing glia progenitors 2 is controversial, because another line of evidence shows that a subset of astrocytes deriving from NG2 expressing glia progenitors is generated only in embryonic or fetal tissue [94]. Thus, reactive astrocyte populations may consist of multiple cell types that are functionally diverse, and the selective detection and manipulation of these subpopulations is proposed to have clinical relevance in a number of conditions related to brain disorders. In vitro studies of reactive astrocytes have demonstrated competitive regulations of astrocyte functions by pro-inflammatory cytokines and growth factors and suggested the existence of diverse types of reactive astrocytes $[95,96]$. In agreement, transcriptome analysis of reactive astrocytes induced by inflammation or brain injury showed distinct gene expression profiles [97], and these reactive astrocytes were designated as A1 and A2 subtypes in subsequent publication [98]. The distinct expression of IF genes is summarized in Figure 2, which is based on the transcriptome databased related to the initial study [97]. Interestingly, GFAP is upregulated in both the A1 and A2 reactive astrocytes, whereas vimentin expression is more prominent, and nestin and plectin appear to be exclusively upregulated in the A2 subtype. It is not clear if microarray data 
included plectin rodless variants. The expression levels of these variants in the mouse brain are approximately 20-times lower compared with the full-length counterparts [99]; however, it is not clear how the reactivation of astrocytes affects their expression levels.

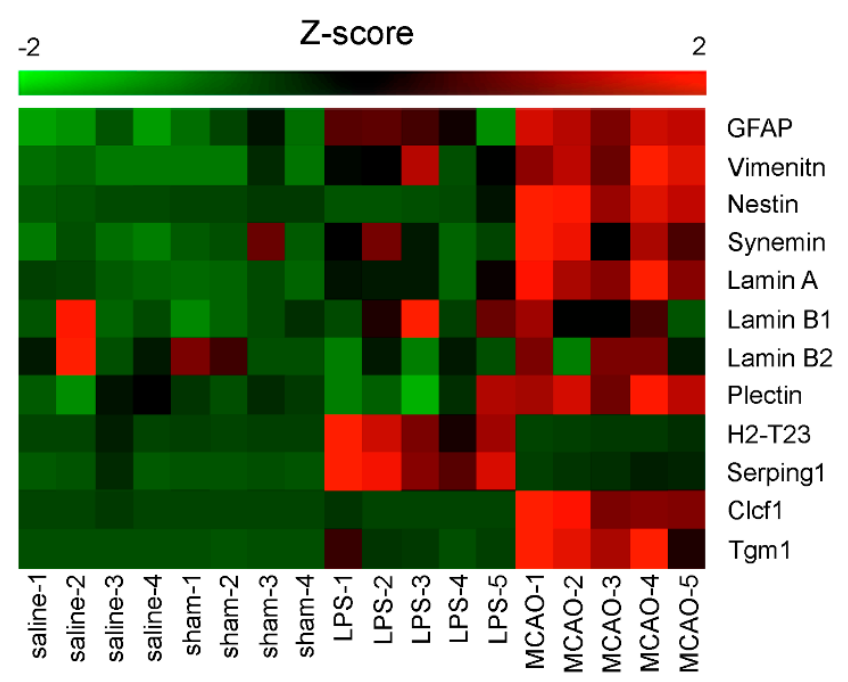

Figure 2. Expression profile of intermediate filament and cytolinker genes in A1 and A2 reactive astrocytes. Microarray data provided in [98] are converted to Z scores and expressed as a heatmap. Saline- 1 to -4 are controls of LPS treatments (A1 reactive astrocytes) and sham- 1 to -4 are controls of MCAO (A2 reactive astrocytes), where LPS is Escherichia coli endotoxin O55:B55 and MCAO stands for transient ischaemia induced by occluding the middle cerebral artery. H2-T23 and Serping 1 are representative genes highly and selectively expressed in the A1 astrocyte subtype, whereas Clcf1 and Tgm 1 are specific for the A2 astrocyte subtype.

Mouse models lacking IFs are a powerful tool for studying the formation and role of IFs in normal or reactive astrocytes in vivo and in astrocyte cultures [41]. The involvement of IFs in the functioning of reactive astrocytes has been studied extensively using $\mathrm{GFAP}^{-/-}$and/or $\mathrm{Vim}^{-/-}$mice. Reactive gliosis in $\mathrm{GFAP}^{-/-} \mathrm{Vim}^{-/-}$mice is generally less pronounced, which is detrimental for the initial spread of the injury; however, it is beneficial for the later regenerative phase [100,101]. Furthermore, the distinct roles of IFs in the A1 and A2 subtypes of reactive astrocytes [98] are suggested in studies of reactive gliosis in various pathological processes. Differences in the parameters of the affected area after brain injury, where predominantly the A2 subtype of reactive astrocytes accumulates, were observed only in the $\mathrm{GFAP}^{-/-} \mathrm{Vim}^{-/}$mice. For example, glial scar formation after stab injury is reduced in the double knockout mice but not in the $G F A P^{-/-}$mice $[48,101]$. Similarly, the infarct size after permanent occlusion of the middle cerebral artery and the lesion size after spinal cord injury are larger in the $\mathrm{GFAP}^{-/-} \mathrm{Vim}^{-/-}$mice [102,103]. Moreover, after brain injury, reactive astrocytes possess fewer and shorter processes in the double knockout mice. These results suggest that vimentin is crucial for neuroprotective A2 astrocytes, whereas GFAP deficiency can be compensated by the upregulation of vimentin and crosslinking capacity of plectin. In contrast, A1 reactive astrocytes, which accumulate in animal models of brain inflammation, were affected in the GFAP ${ }^{-/-}$mice, presumably due to the lower level of vimentin and plectin upregulation. Reactive astrocytes in an Alzheimer's disease model were identified as the A1 subtype by gene profile analysis [98], and the reaction of astrocytes to $\beta$-amyloid was suppressed in the GFAP ${ }^{-/-}$mice [104]. The progression of neurodegeneration in a brain autoimmune disease, called experimental autoimmune encephalomyelitis, was accelerated in the $G F A P^{-/-}$mice, reflecting the incomplete formation of the glial border surrounding a lesion [105]. The accumulation of reactive astrocytes after cerebral bacterial infection was suppressed in the GFAP $P^{--}$ mice, resulting in an increase in immune cell infiltration [106]. This line of evidence suggests that the IFs of A1 reactive astrocytes are largely composed of GFAP alone, and the ablation of GFAP is sufficient for suppressing hypertrophic morphology. 


\section{Nestin}

\subsection{Structure of Nestin}

Nestin is one of the earliest expressed IFs during brain development and is still regarded as a neural progenitor cell (NPC) marker. The discovery of nestin coincides with a search for suitable markers of major cell types in the developing nervous system. Hockfield and McKay observed that antibody "Rat-401" identified proliferating cells in the early neural tube of rats [50]. The epitope recognized by Rat-401 was shown to belong to a protein that was encoded by a gene specifically expressed in neuroepithelial stem cells and thus named nestin [107]. True to its name, nestin expression was shown to be downregulated after the differentiation of NPCs into neurons or glial cells [108,109]. Nonetheless, ensuing studies revealed that nestin expression is more promiscuous than suggested initially; in addition to NPCs, other proliferative cell types, such as myoblasts and cancer cells (nestin is a useful marker of high-grade gliomas [110]) and even a subpopulation of microglia, have been reported to express nestin [111-115]. Moreover, together with vimentin and synemin, nestin is also expressed in immature astrocytes $[69,116]$. The expression of nestin depends on the ubiquitin proteasome system, similar to other IFs [117], and is restarted in reactive astrocytes [41,118,119], as further elaborated in Section 2.1.

Nestin can form homodimers and homotetramers in vitro but cannot form IFs per se (similar to synemin). In astrocytes, nestin can form heteropolymeric filaments with either vimentin or GFAP as obligatory partners $[41,48,120,121]$. In accordance, different GFAP isoforms were shown to control intermediate filament network dynamics, including those of nestin [122]. The intricate collaboration of different types of IFs in filament formation is governed by the structure of individual IFs and the nature of their interaction. In this respect, the interaction between the acidic $\alpha$-helical rods and the basic N-terminal head domain is critical for the formation of IFs. In the case of keratins and vimentin, the complete removal of the head domain was shown to impair IF assembly beyond tetramers [123,124]. In contrast to the extremely long tail domain (more than 1300 amino acids in human and 1500 in rat nestin $[30,125])$, the nestin head domain consists of only six amino acids. For comparison, the head domain of vimentin and GFAP is composed of 82 and 48 amino acids, respectively [126]. Therefore, the relatively small head domain of nestin appears to be the key structure that precludes nestin assembling in filaments on its own.

Upon its identification, nestin was recognized to possess a unique structure and thus became the prototype for a new IF protein group: Type VI [107]. Nestin shares a common structure with the other IFs (as recently reviewed in detail in [127]) and exhibits gene structure and protein similarities, especially with neurofilaments. Consequently, it was proposed that nestin should be placed, together with neurofilaments, in Group IV IFs [125]; however, the unique $\alpha$-helical region and the presence of a third intron in the nestin gene were finally decisive for nestin to be classified in a distinct group - Group VI. Nestin did not occupy Group VI of IFs alone for long. The sequencing of synemin [54], as well as discoveries of tanabin (IF expressed in amphibians [128]) and transitin (IF expressed in birds [129]), eventually joined nestin in Group VI IFs [130].

\subsection{Expression and Function of Nestin in Astrocytes}

Our knowledge of the functions of nestin in astrocytes is still very limited. Functions of nestin may also be linked to its localization. The pattern of nestin distribution in astrocytes shows that nestin protein and nestin mRNA are more prominently localized in cell protrusions than GFAP and vimentin. Nestin's extensive localization in astrocyte protrusions may have an important effect on the reorganization of astrocyte morphology during CNS development and maintenance [131].

The upregulation of IFs (GFAP, vimentin) in astrocytes has a neuroprotective role in the initial phase of brain injury, yet in the regenerative phases, it might also exhibit certain negative effects $[100,101]$. Accordingly, downregulation of the expression of IFs at the later phases of brain injury may improve the neurosupportive properties of astrocytes. Clomipramine, which is classified as a tricyclic antidepressant, 
was shown to be a promising candidate for this task. Clomipramine did not affect astrocyte resilience to oxidative stress; it decreased the protein levels of GFAP, vimentin and nestin and promoted the attachment and survival of neurons co-cultured with astrocytes [132]. However, nestin is not relevant solely in the reactive astrocytes of injured brains, because nestin is also apparently expressed in a subset of astrocytes in the unchallenged hippocampus. Moreover, the expression of nestin in astrocytes negatively regulates adult neurogenesis; this effect is mediated by notch signaling, which is crucial in the differentiation stages of stem cells $[51,133]$. Nestin-containing cells, including immature astrocytes, produce Notch1 mRNA [134]. Notch1 is one of the three Notch receptors involved in the elaborate signaling system that plays many important roles in development and has been shown to promote the proliferation and differentiation of reactive astrocytes, in particular within the subventricular zone $[135,136]$. The absence of nestin in astrocytes likely impairs notch signaling by affecting trafficking as well as the exo- and endocytosis of vesicles containing the Notch ligand, Jagged-1 [137,138]. As a functional consequence of impaired notch signalling, nestin-deficient $\left(\mathrm{Nes}^{-/}\right)$mice showed improved (reversal place) learning as well as memory extinction on account of facilitated forgetting [51,139].

It has been proposed that, in progenitor cells, nestin, through promoting the disassembly of vimentin filaments, has an important effect on the trafficking and delivery of IF proteins and other cellular elements to daughter cells during cell division [140]. Cytoplasmic IFs, including nestin, are involved in a dynamic turnover, which depends on intracellular retrograde and anterograde transport, mediated by actin and microtubule meshworks, yet they also influence cell mobility. Wound-induced astrocyte polarization induces the protein kinase C-dependent inhibition of dynein-dependent retrograde transport, which promotes IF transport directed towards the cell front [141]. In turn, IFs (vimentin, GFAP and nestin), in combination with the cytolinker plectin, govern the collective migration of astrocytes by participating in the dynamics of the acto-myosin network [44]. The genetic ablation of nestin alone is sufficient to cause a significant decrease in astrocyte migration [51]. The crosstalk between the acto-myosin network and microtubules during the mobility of astrocytes is mediated by adenomatous polyposis coli (APC), which is known to be a tumor suppressor, regulating cell differentiation [142]. These results validate the active participation of IFs in astrocytes in adult neurogenesis, CNS regulation and plasticity.

\section{Synemin}

\subsection{Structure and Expression of Synemin}

Synemin, a high-molecular-weight polypeptide, was first isolated from smooth and skeletal muscle from chicken [52]. Later, it was discovered that human smooth and striated muscles express two synemin isoforms $-\alpha$ synemin and $\beta$ synemin (desmuslin) — that are encoded by a single gene $[53,54]$. On the other hand, mouse skeletal muscles express three isoforms: $\mathrm{H}$ and $\mathrm{M}$ isoforms, which are similar in size to human $\alpha(180 \mathrm{kDa})$ and $\beta(150 \mathrm{kDa})$ synemin, respectively, and a much smaller $\mathrm{L}$ isoform (41 kDa) [143].

The expression of synemin in astrocytes was initially shown for rat brain [69] and subsequently demonstrated by several other studies. Its expression follows a developmental pattern, whereby subpopulations of astrocytes in cerebral cortices of rat embryos, new-born and postnatal pups were shown to express synemin, whereas the cortices of adult ( $>60$ days old) rats were devoid of synemin [69]. A similar developmental pattern of synemin expression was detected in mouse primary cultures of GFAP and vimentin positive glial cells, prepared from embryonal (E16) brain and dorsal root ganglia, where synemin also showed a decrease in expression during development [144]. Similarly, adult astrocytes of rabbit spinal cord also lack synemin [145]. Interestingly, however, astrocytes in adult bovine and rabbit optic nerves and astrocytes in adult rat retina express at least low levels of synemin $[145,146]$. Beside the CNS, synemin was also found in rabbit non-myelin-forming Schwann cells of the peripheral nervous system [145]. 
In contrast to muscle cells [143], astrocytes and other glial cells (ependymal cells, Schwann cells), along with neural precursors, express $\mathrm{H}$ and $\mathrm{M}$ synemin isoforms. There are no reports that astrocytes also express the third isoform, $\mathrm{L}$ synemin. Although neurons in rat cerebral cortices are reported to be apparently devoid of synemin [69], L synemin was detected in the neurons and ependymal cells of adult mice, as well as in neurons differentiated from mouse pluripotent embryonal stem cells [144,147]. In addition, human astrocytic tumors contain the $\mathrm{H}$ and $\mathrm{M}$ synemin orthologues $\alpha$ synemin and $\beta$ synemin [55].

\subsection{Subcellular Localization of Synemin}

Synemin was found closely associated with desmin and vimentin when discovered in myotubes, suggesting that it either interacts with other IFs or co-polymerizes with them [52]. Later, both assumptions proved accurate. In mammalian muscle tissue, both $\alpha$ - and $\beta$ synemin were shown to be incorporated with desmin into heteropolymeric IFs [54]. In addition, experiments in mouse astrocytes demonstrated that $\alpha$ synemin interacts with other IFs, namely with GFAP and vimentin filaments [68]. It appears that synemin interacts with GFAP as an IF-associated protein, whereas with vimentin, it acts as a polymerization partner that may function as an adaptor protein to enable synemin incorporation into GFAP filaments [68]. It was proposed that synemin functions as a key crosslinking protein that connects different cytoskeletal components [120,148], but thus far this theory has not been properly tested in astrocytes. Synemin's inability to polymerize into filaments without a binding partner may be due to its short (10 amino acids) head domain, which is much smaller compared with the roughly ten-times longer head domains of vimentin or desmin [54]. The ability of synemin to interact with other proteins originates from its long C-terminal tail domain that can link heteropolymeric IFs to other cytoplasmic components, such as vinculin and $\alpha$-actinin, in striated muscle cells $[120,148]$.

Knowledge about the interactions of synemin with different cytoskeleton proteins, along with its subcellular distribution in astrocytes, is limited. The small number of studies that have dealt with this issue have shown that the subcellular localization of synemin in astrocytes is heterogeneous. Synemin can be found along the dense IF network around the nucleus, yet it is also present along dispersed fibers in other cell regions [68]. Similarly, little is known about the detailed association with other cytoskeletal proteins in astrocytes. In cultured astrocytes from mouse, where IF protein composition resembles that of reactive astrocytes, synemin apparently does not co-localize with IF network-linked structures rich in $\alpha$-actinin or vinculin [68]. Nevertheless, synemin's presence in the ruffled parts of the plasmalemma of human astrocytoma cells, which are rich in $\alpha$-actinin, opens the possibility that, in tumors, synemin may interact with cell membranes and possibly play a role in cell motility [55].

\subsection{Synemin in Reactive Astrocytes}

When astrocytes become reactive, they start to express synemin, as was shown after neurotrauma in mice and in human reactive astrocytes, where the expression of synemin was confirmed around ischaemic lesions or epileptic foci [55]. Similar to the CNS, the upregulation of synemin has been reported in retinal astrocytes in adult rats [146]. Therefore, the expression of synemin in reactive astrocytes may be another promising marker for reactive gliosis in adults [68]. Reactive astrocytes express synemin, which is predominately, but not exclusively, present in GFAP-positive astrocytes [68]. In addition to reactive astrocytes in mice, synemin's presence has been immunohistochemically documented in the human tissue of patients with Alexander disease [65]. Synemin was also detected in many among the GFAP-positive reactive astrocytes in Rosenthal fibers, where it aggregated with GFAP, the small stress proteins, HSP27 and $\alpha$ B-crystallin [65].

Further studies are needed to elucidate the meaning of specific synemin interactions with other cytoskeleton proteins. With understanding of its developmentally regulated, as well as cell type-specific expression pattern, including its expression in injured neuronal tissue (reactive astrocytes), we will get a deeper insight into synemin's physiological (and pathological) functions. 


\section{Lamins}

Unlike the other IFs, which are predominantly cytoplasmic, lamins form a scaffold in the nucleoplasm, primarily at the nuclear periphery. In vertebrate cells, lamins were initially described by Fawcett [149], who suggested (in 1966) that apart from the structural support, other functions of "fibrous lamina" should be considered. This conclusion was drawn from the comparison of nuclear size and the thickness/presence of this layer in cells of vertebrates and invertebrates. Today, lamins are regarded as the only IFs that are universally expressed in metazoans [150]; in the 1960s, there were only a few reports on the nuclear lamina. Nonetheless, Fawcett's suggestion proved to be appropriate, because, analogous to other IFs, lamins are responsible not only for maintaining the structural integrity of the nucleus but they also participate in a multitude of other cellular functions, including higher-order genome organization, the regulation of chromatin, DNA replication and repair, and nuclear assembly/disassembly [151,152]. Ten years after their fibrous nature was described in vertebrate cells, Aaronson and Blobel [153] reported that nuclear lamina contains three major structurally related polypeptides, which were later named lamins A, B and C [154]. The ensuing biochemical characterization of lamins, isolated from baby hamster kidney cells and cDNA cloning (human T cells), have classified nuclear lamins as Type V IFs [155,156].

In mammalian somatic cells, four major lamin isoforms are expressed: lamins $\mathrm{A}$ and $\mathrm{C}$, which are classified into A-type lamins (encoded by the LMNA gene) and lamins B1 and B2, which represent B-type lamins (encoded by the LMNB1 and LMNB2 genes, respectively) [151]. In glial cells, lamins (intranuclear fibrils) were first reported in the ventral nerve cord of the leech Hirudo medicinalis [157]. In vertebrates, biochemical and immunohistochemical studies confirmed the presence of lamins in the brain in the 1980s [158,159]. Soon after, their expression was also identified in all glial (and neuronal) cells in rat CNS [160]. However, not all lamin isoforms are expressed simultaneously during development. Lamins $\mathrm{A}$ and $\mathrm{C}$ are largely lacking in the developing embryo (mouse) brain (as well as from several types of epithelial tissues), because their expression in the brain occurs only several days after birth [161,162]. Conversely, all embryonic cells that are lamin A and C negative are lamin B positive [161], and lamin B1 levels apparently modulate the differentiation of murine neural stem cells (NSCs) into neurons (NSCs expressing high levels of lamin B1) and astroglial-like cells (NSCs expressing low levels of lamin B1) [163]. In adult animals, lamins A and C are found in similar amounts in most tissues, aside from the brain (with the exception of endothelial and meningeal cells). This disproportion has been linked to the expression of a brain-specific microRNA, miR-9; glial cells and neurons of mice express high levels of miR-9, which results in the downregulation of prelamin and lamin A, but not lamin C expression [164]. In agreement, a recent report corroborated that adult rat astrocytes showed immunoreactivity for lamins B1, B2 and C, but not for lamin A [165]; however, some of the lamin A-positive astrocytes that did not express GFAP (marker used by the authors) may have been missed in this report.

Many important roles of lamins in the structural organization of the nucleus and chromatin, as well as genome regulation, have been discovered in the past two decades (reviewed in [151,152]). Some of their functions are exerted by the direct binding of lamins to different replication and transcription factors (e.g., proliferating cell nuclear antigen [57]), whereas other functions are indirect and are mediated by lamin-binding proteins, such as emrin [166]. As the major component of lamina-genome interaction, lamins most likely are also involved in the control of gene expression programs during the lineage committed differentiation of neural precursor cells into astrocytes [167]. Noteworthy, some of the lamin-binding proteins also connect lamins to the cytoplasm, including to the cytoskeleton. The interaction to the cytoskeleton involves the linker of the nucleoskeleton and cytoskeleton (LINC) complex, which connects lamins to the actin and intermediate filament cytoskeletons via direct or plectin-mediated interactions [168,169]. 
Lamins and Diseases

The research interest in lamins gained traction in the 1990s, when mutations in genes encoding proteins of the nuclear lamina, especially lamins, were shown to cause different pathologies $[170,171]$. Since then, around 15 diseases, which are also known under the name laminopathies, were linked to mutations in Lamin genes in humans [172]. Most of the laminopathies, such as lipodystrophy, cardiac dystrophy, muscular dystrophy and skin or bone defects, affect tissues of mesodermal origin [173]. Charcot-Marie-Tooth (CMT) disease encompasses a heterogeneous group of genetic disorders, which is characterized by the loss of peripheral nerve myelination, affecting both the motor and sensory nerves. Certain mutations in LMNA can cause CMT [174], but the CNS in LMNA knockout mice is unaffected [175]. Nonetheless, clinical features typical of a CMT neuropathy have been observed in patients with Fragile X-associated tremor/ataxia syndrome (FXTAS) [176]. FXTAS is a neurodegenerative disorder with heterogeneous clinical presentation, initiated by a CGG repeat expansion in the fragile $X$ mental retardation 1 gene, which manifests as intranuclear inclusions in neurons and astrocytes [177]. The presence of lamin A and C in the neuronal and astrocytic intranuclear inclusions of FXTAS resembles the histopathology of some disease-forming LMNA mutations, which suggests a functional connection between FXTAS and CMT-type neuropathies $[178,179]$. Duchenne muscular dystrophy is another muscular disorder in which (CNS-related) cognitive disturbances and neuropsychiatric symptoms are prevalent. In this case, they are attributed, among others, to mutation in the Dp71 variant protein, which is expressed in neurons and glial cells [180]. Interestingly, the expression of Dp71, which co-localizes with lamin B in healthy astrocytes, is decreased in glioblastoma cells and localized in the cytoplasm, whereas the expression of lamin B is increased [181]. Lamins A and C, on the other hand, play a prominent role in the transport of neurofibromin to the nucleus in astrocytes and glioblastoma cells [58]. Neurofibromin is a tumor suppressor that regulates RAS signaling in the cytoplasm, and hence also its downstream mediators, PI3K (phosphatidylinositol 3-kinase)/mTOR (mammalian target of rapamycin) [182]. mTOR plays a crucial role in regulating autophagy, which has been observed in astrocytes in conditions mimicking those present at ischaemic stroke and was accompanied by lamin A cleavage [183].

Lamins in astrocytes have been proposed to also play a role in viral infections (lamins A and C may promote virus egress [184]), amyotrophic lateral sclerosis (GFAP-expressing astrocytes in lumbar spinal cord express nuclear p16 ${ }^{\mathrm{INK} 4 a}$, which is typically accompanied by the loss of lamin B1 [185]) and even during chronic alcohol exposure (the decreased expression and redistribution of lamins $\mathrm{A}$ and $\mathrm{C}$ affect nucleocytoplasmic transport [59]). Further investigation is warranted to gain full insights into lamin-related functions in astrocytes and, especially, to define the clinical significance of the astrocytic phenotypes in certain laminopathies.

\section{Cytolinkers and Related Proteins}

\subsection{Structure and Expression in Astrocytes}

In eukaryotic cells, the three main types of cytoskeletal filaments form highly organized networks, which are interconnected by crosslinking proteins that also ensure their anchorage to junctional complexes. The crosstalk between different cytoskeletal filament systems, mediated by crosslinking proteins, is essential for a variety of biological processes in the which synchronous response of more than one filament type is required, such as in cell migration. Giant cytolinkers of the plakin/spectraplakin family of proteins represent some of the most important cytoskeletal linker elements [186,187]. Of the nine family members discovered to date, seven have been identified in mammals: bullous pemphigoid antigen 1 (BPAG1; also known as dystonin), microtubule actin crosslinking factor 1 (MACF1; also called ACF7 [188], trabeculin [189] and macrophin [190]), plectin, desmoplakin, envoplakin, periplakin and epiplakin [191]. With the exception of MACF1 and epiplakin, mammalian plakins share a plakin domain (consisting of two stretches of spectrin repeats separated by a Src-Homology 3 [SH3] domain) that mediates protein-protein interactions. In addition, individual plakins comprise distinct combinations 
of various domains, including an actin binding domain (ABD), coiled-coil rod domains of varied lengths, spectrin repeat-containing rod domains, different numbers of plectin/plakin-repeat domains, EF-hand motifs, a growth arrest specific 2 (GAS2)-related protein (GAR) domain and a domain containing a series of glycine-serine-arginine (GSR) repeats. Interestingly, of all the members of the plakin family, only plectin has been unambiguously shown to be expressed in astrocytes [192,193].

Nonetheless, a few reports indicate that desmoplakin might be present in human astrocytes in certain conditions, given that electron microscopy has revealed structures similar to desmosomes [194,195]. Desmosomes are a type of adhesive protein complex, specialized to form stable adhesive junctions between cells with which the N-terminal head domain of desmoplakin associates [196]. Similarly, astrocytes possess membrane structures that resemble hemidesmosomes (HDs) [195]. HDs are specialized integrin-mediated attachment structures that ensure the adherence of cells to the extracellular matrix by firmly anchoring IF networks [197]. Integrin $\alpha 6 \beta 4$, which is one of the two transmembrane components of mature (Type I) HDs, was identified in astrocytes [198]; however, BPAG1, which was initially discovered as a hemidesmosomal protein in keratinocytes [199], has thus far not been discovered in astrocytes, defining the astrocytic HD-like structures as Type II HDs. Considering that astrocytic morphological plasticity significantly depends on actin and tubulin [200], one would expect that MACF1, which interacts with microtubules and F-actin via distinct microtubule and actin-binding domains, is expressed in astrocytes. However, MACF1, although with confirmed expression in multiple tissues throughout the body [201], has only been identified in astrocytomas and glioblastomas, but not in normal brain tissue [202].

\subsection{Plectin}

The rat glioma cell line C6, in which plectin was first identified [203], is an experimental model system for the study of glioblastoma. Several years after the initial discovery, plectin expression was also confirmed in normal astrocytes [192,204] as well as in most other mammalian cell types [205,206]. IFs are one of the most important binding partners of plectin. Plectin was originally isolated as a major component of IFs extracted from cell lysates [203]. All plectin isoforms contain a high-affinity IF-binding site at their $\mathrm{C}$ termini, which mediates the targeting and anchorage of IFs at different, clearly defined cellular locations [207]. The remarkable isoform diversity of plectin is a consequence of differential splicing of 12 alternative first exons into a common exon 2, which is the first of seven exons (exons 2-8) encoding plectin's ABD $[207,208]$; however, three of the alternative first exons are non-coding, giving rise to isoforms with truncated $\mathrm{ABDs}$. The $\mathrm{ABD}$ of plectin is relatively well conserved and similar to the ABDs in spectrin, dystrophin, BPAG1 and MACF/ACF7 [209]; however, it is unique in presenting with two short exons $(2 \alpha, 3 \alpha)$ that optionally splice into the ABD sequence, resulting in three different ABD isoforms [210]. The CH1 subdomain of plectin's ABD contains another binding site for IFs, which likely favours the binding of soluble vimentin [210]. In general, the interaction of plectin with vimentin and lamin B was shown to be differentially regulated by protein kinase A and C [211,212]. In primary astroglial cells, a functional manifestation of plectin deficiency was reported regarding cAMP-dependent signaling pathways, because the cells showed a delay in cAMP-stimulated morphological differentiation [213]. Morphological (and functional) adaptations of astrocytes (i.e., reactive astrogliosis) are especially important as responses to CNS injury [101]. Considering the interdependence of plectin and IFs, it is not surprising that, in reactive astrocytes (specifically in the A2 subtype), the augmented expression of GFAP and vimentin is accompanied by the increased expression of plectin [193], as shown in Figure 2. Hence, it is reasonable to assume that plectin plays an important role in reactive astrogliosis. However, further research is needed to shed light on the mechanism and pecking order of IF and plectin action that leads to the resulting physiological response. Some parallels can be drawn from the involvement of plectin in Alexander disease, a rare progressive neurodegenerative disorder caused by dominantly acting mutations in GFAP. Rosenthal fibers are the hallmark of this disease (i.e., cytoplasmic proteinaceous aggregates in astrocytes [63], which, among other proteins, contain plectin and GFAP). Although the disease results in increased expression 
levels of plectin and GFAP in the brain, the proportion of both proteins appears to be relevant as well [64]. The overexpression of plectin cDNA converted these aggregates to networks composed of thin filaments, whereas the expression of GFAP with the most common Alexander disease mutation lowered plectin levels. These results suggest that insufficient amounts of plectin promote GFAP aggregation and the formation of Rosenthal fibers in Alexander disease [64]. However, the disease most frequently associated with plectin deficiency is epidermolysis bullosa simplex with muscular dystrophy (EBS-MD), a subtype of EBS. EBS, which happens to be the first disease identified involving IFs [214,215], is characterized by intraepidermal skin split (i.e., blistering of the skin). Mutations in the human plectin gene may result in autosomal recessive EBS-MD, EBS-MD with myasthenic features (EBS-MD-MyS), EBS with pyloric atresia (EBS-PA) limb girdle muscular dystrophy type 2Q (LGMD2Q), skin-only EBS [216] and the autosomal dominant variant EBS-Ogna [207,217].

The binding versatility of plectin is not limited to IFs, because plectin can associate with microtubules (directly or via microtubule-associated proteins) and actin filaments, the nuclear envelope, transmembrane receptors, proteins of the plasma membrane protein skeleton, mitochondria and signal transducers, such as kinases involved in migration and proliferation $[205,213,218]$. These interactions are mirrored by plectin's multiple functions in practically all mammalian cell types [205,207]. However, considering the importance of IFs in astrocytes, coupled with the relatively limited amount of knowledge of cytolinker proteins and other cytoskeletal macromolecules in this cell type, there is no doubt that further research is warranted.

\section{Conclusions}

Astrocytes and IFs share humble beginnings in the literature, as studies of both were overshadowed by those performed on neurons and microtubules/actin filaments, respectively. The primary reason for the early absence of research interest in astrocytes and IFs is that, initially, both were perceived to provide solely mechanical support and were considered to be static in nature. In contrast, in the last few decades astrocytes have been shown to possess numerous functions in the CNS, the sum of which apparently exceeds those performed by neurons. Similarly, IFs have been demonstrated to be not only significantly more diverse, compared to microtubules/actin filaments, but to participate in a variety of dynamic processes, such as in cell signaling.

Astrocytes are implicated to be actively involved in many CNS pathologies, either directly or indirectly. These pathologies result in the hypertrophy of astrocytic processes, a process that is known as reactive gliosis and encompasses a variety of biochemical, molecular, and morphologic events. The nature of reactive gliosis is highly heterogeneous and can, depending on the circumstances, either protect or perpetuate the underlying disease. A hallmark of reactive gliosis is the upregulation of certain IFs, namely of GFAP, vimentin, nestin and also, in some reactive astrocytes, synemin. Significant progress has been made in recent years in our understanding of the molecular mechanisms by which these IFs are orchestrating reactive gliosis. Considering that different IFs are interacting with each other and with various proteins, the whole IF scaffold is effectively implicated in practically all cellular processes. In order to fill the gaps in the current knowledge of individual IFs and their complex networks in astrocytes, both in physiological and pathological settings, a great deal of work remains to be done. In addition, two key challenges will be: (i) to assess the role of lamins in reactive gliosis, bearing in mind their capacity to regulate genes in a response to mechanical cues; (ii) to learn how the considerable complexity of cytolinker proteins, such as plectin and other cytoskeletal macromolecules, contribute to different stages of reactive gliosis.

Funding: This research was funded by the Slovenian Research Agency (grant numbers P3 310, J3 7605 and J3-9266); by JSPS KAKENHI (grant numbers 17K07110 and 18KT0071); by Slovenian-Japanese joint project (grant number BI-JP/18-20-002); by EuroCellNet COST Action (grant number CA15214).

Acknowledgments: We kindly acknowledge Sunhwa Gang and Daichi Hatano for their help with the analysis.

Conflicts of Interest: The authors declare no conflict of interest. 


\section{References}

1. Zorec, R.; Araque, A.; Carmignoto, G.; Haydon, P.G.; Verkhratsky, A.; Parpura, V. Astroglial excitability and gliotransmission: An appraisal of $\mathrm{Ca}^{2+}$ as a signalling route. ASN Neuro 2012, 4. [CrossRef]

2. Glickstein, M. Golgi and Cajal: The neuron doctrine and the 100th anniversary of the 1906 Nobel Prize. Curr. Biol. 2006, 16, R147-R151. [CrossRef]

3. Eng, L.F.; Vanderhaeghen, J.J.; Bignami, A.; Gerstl, B. An acidic protein isolated from fibrous astrocytes. Brain Res. 1971, 28, 351-354. [CrossRef]

4. $\quad$ Barres, B.A.; Koroshetz, W.J.; Chun, L.L.; Corey, D.P. Ion channel expression by white matter glia: The type-1 astrocyte. Neuron 1990, 5, 527-544. [CrossRef]

5. Cornell-Bell, A.H.; Finkbeiner, S.M.; Cooper, M.S.; Smith, S.J. Glutamate induces calcium waves in cultured astrocytes: Long-range glial signaling. Science 1990, 247, 470-473. [CrossRef]

6. Charles, A.C.; Merrill, J.E.; Dirksen, E.R.; Sanderson, M.J. Intercellular signaling in glial cells: Calcium waves and oscillations in response to mechanical stimulation and glutamate. Neuron 1991, 6, 983-992. [CrossRef]

7. Dani, J.W.; Chernjavsky, A.; Smith, S.J. Neuronal activity triggers calcium waves in hippocampal astrocyte networks. Neuron 1992, 8, 429-440. [CrossRef]

8. Nedergaard, M. Direct signaling from astrocytes to neurons in cultures of mammalian brain cells. Science 1994, 263, 1768-1771. [CrossRef]

9. Parpura, V.; Basarsky, T.A.; Liu, F.; Jeftinija, K.; Jeftinija, S.; Haydon, P.G. Glutamate-mediated astrocyte-neuron signalling. Nature 1994, 369, 744-747. [CrossRef]

10. Araque, A.; Parpura, V.; Sanzgiri, R.P.; Haydon, P.G. Tripartite synapses: Glia, the unacknowledged partner. Trends Neurosci. 1999, 22, 208-215. [CrossRef]

11. Potokar, M.; Vardjan, N.; Stenovec, M.; Gabrijel, M.; Trkov, S.; Jorgačevski, J.; Kreft, M.; Zorec, R. Astrocytic vesicle mobility in health and disease. Int. J. Mol. Sci. 2013, 14, 11238-11258. [CrossRef] [PubMed]

12. Potokar, M.; Stenovec, M.; Gabrijel, M.; Li, L.; Kreft, M.; Grilc, S.; Pekny, M.; Zorec, R. Intermediate filaments attenuate stimulation-dependent mobility of endosomes/lysosomes in astrocytes. Glia 2010, 58, 1208-1219. [CrossRef] [PubMed]

13. Potokar, M.; Kreft, M.; Li, L.; Daniel Andersson, J.; Pangrsic, T.; Chowdhury, H.H.; Pekny, M.; Zorec, R. Cytoskeleton and vesicle mobility in astrocytes. Traffic 2007, 8, 12-20. [CrossRef] [PubMed]

14. Margiotta, A.; Bucci, C. Role of intermediate filaments in vesicular traffic. Cells 2016, 5, 20. [CrossRef]

15. Kimelberg, H.K. The problem of astrocyte identity. Neurochem. Int. 2004, 45, 191-202. [CrossRef]

16. Eriksson, J.E.; Dechat, T.; Grin, B.; Helfand, B.; Mendez, M.; Pallari, H.M.; Goldman, R.D. Introducing intermediate filaments: From discovery to disease. J. Clin. Investig. 2009, 119, 1763-1771. [CrossRef]

17. Hesse, M.; Magin, T.M.; Weber, K. Genes for intermediate filament proteins and the draft sequence of the human genome: Novel keratin genes and a surprisingly high number of pseudogenes related to keratin genes 8 and 18. J. Cell Sci. 2001, 114, 2569-2575.

18. Hol, E.M.; Pekny, M. Glial fibrillary acidic protein (GFAP) and the astrocyte intermediate filament system in diseases of the central nervous system. Curr. Opin. Cell Biol. 2015, 32, 121-130. [CrossRef]

19. Sofroniew, M.V.; Vinters, H.V. Astrocytes: Biology and pathology. Acta Neuropathol. 2010, 119, 7-35. [CrossRef]

20. Fraser, R.D.; Macrae, T.P. The molecular configuration of alpha-keratin. J. Mol. Biol. 1961, 3, $640-647$. [CrossRef]

21. Goldman, R.D.; Follett, E.A. Birefringent filamentous organelle in BHK-21 cells and its possible role in cell spreading and motility. Science 1970, 169, 286-288. [CrossRef]

22. Goldman, R.D. The role of three cytoplasmic fibers in BHK-21 cell motility. I. Microtubules and the effects of colchicine. J. Cell Biol. 1971, 51, 752-762. [CrossRef] [PubMed]

23. Ishikawa, H.; Bischoff, R.; Holtzer, H. Mitosis and intermediate-sized filaments in developing skeletal muscle. J. Cell Biol. 1968, 38, 538-555. [CrossRef]

24. Starger, J.M.; Goldman, R.D. Isolation and preliminary characterization of 10-nm filaments from baby hamster kidney (BHK-21) cells. Proc. Natl. Acad. Sci. USA 1977, 74, 2422-2426. [CrossRef] [PubMed]

25. Starger, J.M.; Brown, W.E.; Goldman, A.E.; Goldman, R.D. Biochemical and immunological analysis of rapidly purified 10-nm filaments from baby hamster kidney (BHK-21) cells. J. Cell Biol. 1978, 78, 93-109. [CrossRef] [PubMed] 
26. Pruss, R.M.; Mirsky, R.; Raff, M.C.; Thorpe, R.; Dowding, A.J.; Anderton, B.H. All classes of intermediate filaments share a common antigenic determinant defined by a monoclonal antibody. Cell 1981, 27, 419-428. [CrossRef]

27. Uyeda, C.T.; Eng, L.F.; Bignami, A. Immunological study of the glial fibrillary acidic protein. Brain Res. 1972, 37, 81-89. [CrossRef]

28. Weber, K.; Geisler, N. Intermediate filaments: Structural conservation and divergence. Ann. N. Y. Acad. Sci. 1985, 455, 126-143. [CrossRef]

29. Lazarides, E. Intermediate filaments as mechanical integrators of cellular space. Nature 1980, 283, $249-256$. [CrossRef]

30. Dahlstrand, J.; Zimmerman, L.B.; McKay, R.D.; Lendahl, U. Characterization of the human nestin gene reveals a close evolutionary relationship to neurofilaments. J. Cell Sci. 1992, 103 Pt 2, 589-597.

31. Rutka, J.T.; Giblin, J.R.; Balkissoon, R.; Wen, D.; Myatt, C.A.; McCulloch, J.R.; Rosenblum, M.L. Characterization of fetal human brain cultures. Development of a potential model for selectively purifying human glial cells in culture. Dev. Neurosci. 1987, 9, 154-173. [CrossRef]

32. Pekny, M.; Pekna, M. Astrocyte intermediate filaments in CNS pathologies and regeneration. J. Pathol. 2004, 204, 428-437. [CrossRef]

33. Budka, H. Non-glial specificities of immunocytochemistry for the glial fibrillary acidic protein (GFAP). Triple expression of GFAP, vimentin and cytokeratins in papillary meningioma and metastasizing renal carcinoma. Acta Neuropathol. 1986, 72, 43-54. [CrossRef]

34. Roelofs, R.F.; Fischer, D.F.; Houtman, S.H.; Sluijs, J.A.; Van Haren, W.; Van Leeuwen, F.W.; Hol, E.M. Adult human subventricular, subgranular, and subpial zones contain astrocytes with a specialized intermediate filament cytoskeleton. Glia 2005, 52, 289-300. [CrossRef]

35. van den Berge, S.A.; Middeldorp, J.; Zhang, C.E.; Curtis, M.A.; Leonard, B.W.; Mastroeni, D.; Voorn, P.; van de Berg, W.D.; Huitinga, I.; Hol, E.M. Longterm quiescent cells in the aged human subventricular neurogenic system specifically express GFAP-delta. Aging Cell 2010, 9, 313-326. [CrossRef]

36. Cahoy, J.D.; Emery, B.; Kaushal, A.; Foo, L.C.; Zamanian, J.L.; Christopherson, K.S.; Xing, Y.; Lubischer, J.L.; Krieg, P.A.; Krupenko, S.A.; et al. A transcriptome database for astrocytes, neurons, and oligodendrocytes: A new resource for understanding brain development and function. J. Neurosci. 2008, 28, 264-278. [CrossRef]

37. Middeldorp, J.; Hol, E.M. GFAP in health and disease. Prog. Neurobiol. 2011, 93, 421-443. [CrossRef]

38. Zoltewicz, J.S.; Scharf, D.; Yang, B.; Chawla, A.; Newsom, K.J.; Fang, L. Characterization of antibodies that detect human GFAP after traumatic brain injury. Biomark. Insights 2012, 7, 71-79. [CrossRef]

39. Reeves, S.A.; Helman, L.J.; Allison, A.; Israel, M.A. Molecular cloning and primary structure of human glial fibrillary acidic protein. Proc. Natl. Acad. Sci. USA 1989, 86, 5178-5182. [CrossRef]

40. Chen, W.J.; Liem, R.K. The endless story of the glial fibrillary acidic protein. J. Cell Sci. 1994, 107 Pt 8, 2299-2311.

41. Eliasson, C.; Sahlgren, C.; Berthold, C.H.; Stakeberg, J.; Celis, J.E.; Betsholtz, C.; Eriksson, J.E.; Pekny, M. Intermediate filament protein partnership in astrocytes. J. Biol. Chem. 1999, 274, 23996-24006. [CrossRef] [PubMed]

42. Potokar, M.; Stenovec, M.; Kreft, M.; Kreft, M.; Zorec, R. Stimulation inhibits the mobility of recycling peptidergic vesicles in astrocytes. Glia 2008, 56, 135-144. [CrossRef] [PubMed]

43. Vardjan, N.; Gabrijel, M.; Potokar, M.; Svajger, U.; Kreft, M.; Jeras, M.; de Pablo, Y.; Faiz, M.; Pekny, M.; Zorec, R. IFN- $\gamma$-induced increase in the mobility of MHC class II compartments in astrocytes depends on intermediate filaments. J. Neuroinflamm. 2012, 9, 144. [CrossRef] [PubMed]

44. De Pascalis, C.; Pérez-González, C.; Seetharaman, S.; Boëda, B.; Vianay, B.; Burute, M.; Leduc, C.; Borghi, N.; Trepat, X.; Etienne-Manneville, S. Intermediate filaments control collective migration by restricting traction forces and sustaining cell-cell contacts. J. Cell Biol. 2018, 217, 3031-3044. [CrossRef]

45. Ding, M.; Eliasson, C.; Betsholtz, C.; Hamberger, A.; Pekny, M. Altered taurine release following hypotonic stress in astrocytes from mice deficient for GFAP and vimentin. Brain Res. Mol. Brain Res. 1998, 62, 77-81. [CrossRef]

46. Franke, W.W.; Schmid, E.; Osborn, M.; Weber, K. Different intermediate-sized filaments distinguished by immunofluorescence microscopy. Proc. Natl. Acad. Sci. USA 1978, 75, 5034-5038. [CrossRef] 
47. Wilhelmsson, U.; Li, L.; Pekna, M.; Berthold, C.; Blom, S.; Eliasson, C.; Renner, O.; Bushong, E.; Ellisman, M.; Morgan, T.; et al. Absence of glial fibrillary acidic protein and vimentin prevents hypertrophy of astrocytic processes and improves post-traumatic regeneration. J. Neurosci. 2004, 24, 5016-5021. [CrossRef]

48. Pekny, M.; Johansson, C.B.; Eliasson, C.; Stakeberg, J.; Wallén, A.; Perlmann, T.; Lendahl, U.; Betsholtz, C.; Berthold, C.H.; Frisén, J. Abnormal reaction to central nervous system injury in mice lacking glial fibrillary acidic protein and vimentin. J. Cell Biol. 1999, 145, 503-514. [CrossRef]

49. de Pablo, Y.; Marasek, P.; Pozo-Rodrigálvarez, A.; Wilhelmsson, U.; Inagaki, M.; Pekna, M.; Pekny, M. Vimentin phosphorylation is required for normal cell division of immature astrocytes. Cells 2019, 8, 1016. [CrossRef]

50. Hockfield, S.; McKay, R.D. Identification of major cell classes in the developing mammalian nervous system. J. Neurosci. 1985, 5, 3310-3328. [CrossRef]

51. Wilhelmsson, U.; Lebkuechner, I.; Leke, R.; Marasek, P.; Yang, X.; Antfolk, D.; Chen, M.; Mohseni, P.; Lasič, E.; Bobnar, S.T.; et al. Nestin regulates neurogenesis in mice through notch signaling from astrocytes to neural stem cells. Cereb. Cortex 2019, 29, 4050-4066. [CrossRef]

52. Granger, B.L.; Lazarides, E. Synemin: A new high molecular weight protein associated with desmin and vimentin filaments in muscle. Cell 1980, 22, 727-738. [CrossRef]

53. Mizuno, Y.; Thompson, T.G.; Guyon, J.R.; Lidov, H.G.; Brosius, M.; Imamura, M.; Ozawa, E.; Watkins, S.C.; Kunkel, L.M. Desmuslin, an intermediate filament protein that interacts with alpha -dystrobrevin and desmin. Proc. Natl. Acad. Sci. USA 2001, 98, 6156-6161. [CrossRef] [PubMed]

54. Titeux, M.; Brocheriou, V.; Xue, Z.; Gao, J.; Pellissier, J.F.; Guicheney, P.; Paulin, D.; Li, Z. Human synemin gene generates splice variants encoding two distinct intermediate filament proteins. Eur. J. Biochem. 2001, 268, 6435-6449. [CrossRef]

55. Jing, R.; Pizzolato, G.; Robson, R.M.; Gabbiani, G.; Skalli, O. Intermediate filament protein synemin is present in human reactive and malignant astrocytes and associates with ruffled membranes in astrocytoma cells. Glia 2005, 50, 107-120. [CrossRef]

56. Kaufmann, S.H.; Gibson, W.; Shaper, J.H. Characterization of the major polypeptides of the rat liver nuclear envelope. J. Biol. Chem. 1983, 258, 2710-2719. [PubMed]

57. Shumaker, D.K.; Solimando, L.; Sengupta, K.; Shimi, T.; Adam, S.A.; Grunwald, A.; Strelkov, S.V.; Aebi, U.; Cardoso, M.C.; Goldman, R.D. The highly conserved nuclear lamin Ig-fold binds to PCNA: Its role in DNA replication. J. Cell Biol. 2008, 181, 269-280. [CrossRef] [PubMed]

58. Koliou, X.; Fedonidis, C.; Kalpachidou, T.; Mangoura, D. Nuclear import mechanism of neurofibromin for localization on the spindle and function in chromosome congression. J. Neurochem. 2016, 136, 78-91. [CrossRef]

59. Marín, M.P.; Tomas, M.; Esteban-Pretel, G.; Megías, L.; López-Iglesias, C.; Egea, G.; Renau-Piqueras, J. Chronic ethanol exposure induces alterations in the nucleocytoplasmic transport in growing astrocytes. J. Neurochem. 2008, 106, 1914-1928. [CrossRef] [PubMed]

60. van Bodegraven, E.J.; van Asperen, J.V.; Robe, P.A.J.; Hol, E.M. Importance of GFAP isoform-specific analyses in astrocytoma. Glia 2019, 67, 1417-1433. [CrossRef] [PubMed]

61. Perng, M.D.; Wen, S.F.; Gibbon, T.; Middeldorp, J.; Sluijs, J.; Hol, E.M.; Quinlan, R.A. Glial fibrillary acidic protein filaments can tolerate the incorporation of assembly-compromised GFAP-delta, but with consequences for filament organization and alphaB-crystallin association. Mol. Biol. Cell 2008, 19, 4521-4533. [CrossRef]

62. Moeton, M.; Kanski, R.; Stassen, O.M.; Sluijs, J.A.; Geerts, D.; van Tijn, P.; Wiche, G.; van Strien, M.E.; Hol, E.M. Silencing GFAP isoforms in astrocytoma cells disturbs laminin-dependent motility and cell adhesion. FASEB J. 2014, 28, 2942-2954. [CrossRef] [PubMed]

63. Sosunov, A.A.; McKhann, G.M., 2nd; Goldman, J.E. The origin of Rosenthal fibers and their contributions to astrocyte pathology in Alexander disease. Acta Neuropathol. Commun. 2017, 5, 27. [CrossRef]

64. Tian, R.; Gregor, M.; Wiche, G.; Goldman, J.E. Plectin regulates the organization of glial fibrillary acidic protein in Alexander disease. Am. J. Pathol. 2006, 168, 888-897. [CrossRef] [PubMed]

65. Pekny, T.; Faiz, M.; Wilhelmsson, U.; Curtis, M.A.; Matej, R.; Skalli, O.; Pekny, M. Synemin is expressed in reactive astrocytes and Rosenthal fibers in Alexander disease. APMIS 2014, 122, 76-80. [CrossRef] [PubMed] 
66. Heaven, M.R.; Flint, D.; Randall, S.M.; Sosunov, A.A.; Wilson, L.; Barnes, S.; Goldman, J.E.; Muddiman, D.C.; Brenner, M. Composition of Rosenthal fibers, the protein aggregate hallmark of Alexander disease. J. Proteome Res. 2016, 15, 2265-2282. [CrossRef] [PubMed]

67. Quinlan, R.A.; Franke, W.W. Molecular interactions in intermediate-sized filaments revealed by chemical cross-linking. Heteropolymers of vimentin and glial filament protein in cultured human glioma cells. Eur. J. Biochem. 1983, 132, 477-484. [CrossRef]

68. Jing, R.; Wilhelmsson, U.; Goodwill, W.; Li, L.; Pan, Y.; Pekny, M.; Skalli, O. Synemin is expressed in reactive astrocytes in neurotrauma and interacts differentially with vimentin and GFAP intermediate filament networks. J. Cell Sci. 2007, 120, 1267-1277. [CrossRef] [PubMed]

69. Sultana, S.; Sernett, S.W.; Bellin, R.M.; Robson, R.M.; Skalli, O. Intermediate filament protein synemin is transiently expressed in a subset of astrocytes during development. Glia 2000, 30, 143-153. [CrossRef]

70. Viedma-Poyatos, Á.; de Pablo, Y.; Pekny, M.; Pérez-Sala, D. The cysteine residue of glial fibrillary acidic protein is a critical target for lipoxidation and required for efficient network organization. Free Radi. Biol. Med. 2018, 120, 380-394. [CrossRef]

71. Ciesielski-Treska, J.; Goetschy, J.F.; Ulrich, G.; Aunis, D. Acquisition of vimentin in astrocytes cultured from postnatal rat brain. J. Neurocytol. 1988, 17, 79-86. [CrossRef] [PubMed]

72. Sharp, G.; Osborn, M.; Weber, K. Occurrence of two different intermediate filament proteins in the same filament in situ within a human glioma cell line. An immunoelectron microscopical study. Exp. Cell Res. 1982, 141, 385-395. [CrossRef]

73. Shaw, G.; Osborn, M.; Weber, K. An immunofluorescence microscopical study of the neurofilament triplet proteins, vimentin and glial fibrillary acidic protein within the adult rat brain. Eur. J. Cell Biol. 1981, 26, 68-82.

74. Wang, E.; Cairncross, J.G.; Liem, R.K. Identification of glial filament protein and vimentin in the same intermediate filament system in human glioma cells. Proc. Natl. Acad. Sci. USA 1984, 81, 2102-2106. [CrossRef] [PubMed]

75. Schnitzer, J.; Franke, W.W.; Schachner, M. Immunocytochemical demonstration of vimentin in astrocytes and ependymal cells of developing and adult mouse nervous system. J. Cell Biol. 1981, 90, 435-447. [CrossRef] [PubMed]

76. Bovolenta, P.; Liem, R.K.; Mason, C.A. Development of cerebellar astroglia: Transitions in form and cytoskeletal content. Dev. Biol. 1984, 102, 248-259. [CrossRef]

77. Ivaska, J.; Pallari, H.M.; Nevo, J.; Eriksson, J.E. Novel functions of vimentin in cell adhesion, migration, and signaling. Exp. Cell Res. 2007, 313, 2050-2062. [CrossRef] [PubMed]

78. Eriksson, J.E.; Opal, P.; Goldman, R.D. Intermediate filament dynamics. Curr. Opin. Cell Biol. 1992, 4, 99-104. [CrossRef]

79. Eriksson, J.; Brautigan, D.; Vallee, R.; Olmsted, J.; Fujiki, H.; Goldman, R. Cytoskeletal integrity in interphase cells requires protein phosphatase activity. Proc. Natl. Acad. Sci. USA 1992, 89, 11093-11097. [CrossRef]

80. Eriksson, J.E.; He, T.; Trejo-Skalli, A.V.; Härmälä-Braskén, A.S.; Hellman, J.; Chou, Y.H.; Goldman, R.D. Specific in vivo phosphorylation sites determine the assembly dynamics of vimentin intermediate filaments. J. Cell Sci. 2004, 117, 919-932. [CrossRef]

81. Wang, K.; Bekar, L.K.; Furber, K.; Walz, W. Vimentin-expressing proximal reactive astrocytes correlate with migration rather than proliferation following focal brain injury. Brain Res. 2004, 1024, 193-202. [CrossRef] [PubMed]

82. Tzivion, G.; Luo, Z.J.; Avruch, J. Calyculin A-induced vimentin phosphorylation sequesters 14-3-3 and displaces other 14-3-3 partners in vivo. J. Biol. Chem. 2000, 275, 29772-29778. [CrossRef] [PubMed]

83. Muslin, A.J.; Lau, J.M. Differential functions of 14-3-3 isoforms in vertebrate development. Curr. Top. Dev. Biol. 2005, 65, 211-228. [CrossRef]

84. Potokar, M.; Stenovec, M.; Jorgačevski, J.; Holen, T.; Kreft, M.; Ottersen, O.P.; Zorec, R. Regulation of AQP4 surface expression via vesicle mobility in astrocytes. Glia 2013, 61, 917-928. [CrossRef]

85. Kamat, P.K.; Swarnkar, S.; Rai, S.; Kumar, V.; Tyagi, N. Astrocyte mediated MMP-9 activation in the synapse dysfunction: An implication in Alzheimer disease. Ther. Targets Neurol. Dis. 2015, 1. [CrossRef]

86. Seifert, G.; Schilling, K.; Steinhäuser, C. Astrocyte dysfunction in neurological disorders: A molecular perspective. Nat. Rev. Neurosci. 2006, 7, 194-206. [CrossRef] 
87. Bush, T.G.; Puvanachandra, N.; Horner, C.H.; Polito, A.; Ostenfeld, T.; Svendsen, C.N.; Mucke, L.; Johnson, M.H.; Sofroniew, M.V. Leukocyte infiltration, neuronal degeneration, and neurite outgrowth after ablation of scar-forming, reactive astrocytes in adult transgenic mice. Neuron 1999, 23, $297-308$. [CrossRef]

88. Okada, S.; Nakamura, M.; Katoh, H.; Miyao, T.; Shimazaki, T.; Ishii, K.; Yamane, J.; Yoshimura, A.; Iwamoto, Y.; Toyama, Y.; et al. Conditional ablation of Stat3 or Socs3 discloses a dual role for reactive astrocytes after spinal cord injury. Nat. Med. 2006, 12, 829-834. [CrossRef]

89. Chung, W.S.; Welsh, C.A.; Barres, B.A.; Stevens, B. Do glia drive synaptic and cognitive impairment in disease? Nat. Neurosci. 2015, 18, 1539-1545. [CrossRef]

90. Clarke, L.E.; Barres, B.A. Emerging roles of astrocytes in neural circuit development. Nat. Rev. Neurosci. 2013, 14, 311-321. [CrossRef]

91. Faiz, M.; Sachewsky, N.; Gascón, S.; Bang, K.W.A.; Morshead, C.M.; Nagy, A. Adult neural stem cells from the subventricular zone give rise to reactive astrocytes in the cortex after stroke. Cell Stem Cell 2015, 17, 624-634. [CrossRef]

92. Honsa, P.; Valny, M.; Kriska, J.; Matuskova, H.; Harantova, L.; Kirdajova, D.; Valihrach, L.; Androvic, P.; Kubista, M.; Anderova, M. Generation of reactive astrocytes from NG2 cells is regulated by sonic hedgehog. Glia 2016, 64, 1518-1531. [CrossRef] [PubMed]

93. Hackett, A.R.; Yahn, S.L.; Lyapichev, K.; Dajnoki, A.; Lee, D.H.; Rodriguez, M.; Cammer, N.; Pak, J.; Mehta, S.T.; Bodamer, O.; et al. Injury type-dependent differentiation of NG2 glia into heterogeneous astrocytes. Exp. Neurol. 2018, 308, 72-79. [CrossRef]

94. Zhu, X.; Hill, R.A.; Dietrich, D.; Komitova, M.; Suzuki, R.; Nishiyama, A. Age-dependent fate and lineage restriction of single NG2 cells. Development 2011, 138, 745-753. [CrossRef] [PubMed]

95. Morita, M.; Saruta, C.; Kozuka, N.; Okubo, Y.; Itakura, M.; Takahashi, M.; Kudo, Y. Dual regulation of astrocyte gap junction hemichannels by growth factors and a pro-inflammatory cytokine via the mitogen-activated protein kinase cascade. Glia 2007, 55, 508-515. [CrossRef] [PubMed]

96. Morita, M.; Higuchi, C.; Moto, T.; Kozuka, N.; Susuki, J.; Itofusa, R.; Yamashita, J.; Kudo, Y. Dual regulation of calcium oscillation in astrocytes by growth factors and pro-inflammatory cytokines via the mitogen-activated protein kinase cascade. J. Neurosci. 2003, 23, 10944-10952. [CrossRef] [PubMed]

97. Zamanian, J.L.; Xu, L.; Foo, L.C.; Nouri, N.; Zhou, L.; Giffard, R.G.; Barres, B.A. Genomic analysis of reactive astrogliosis. J. Neurosci. 2012, 32, 6391-6410. [CrossRef]

98. Liddelow, S.A.; Guttenplan, K.A.; Clarke, L.E.; Bennett, F.C.; Bohlen, C.J.; Schirmer, L.; Bennett, M.L.; Münch, A.E.; Chung, W.S.; Peterson, T.C.; et al. Neurotoxic reactive astrocytes are induced by activated microglia. Nature 2017, 541, 481-487. [CrossRef]

99. Fuchs, P.; Spazierer, D.; Wiche, G. Plectin rodless isoform expression and its detection in mouse brain. Cell Mol. Neurobiol. 2005, 25, 1141-1150. [CrossRef]

100. Pekny, M.; Wilhelmsson, U.; Pekna, M. The dual role of astrocyte activation and reactive gliosis. Neurosci. Lett. 2014, 565, 30-38. [CrossRef]

101. Pekny, M.; Pekna, M. Astrocyte reactivity and reactive astrogliosis: Costs and benefits. Physiol. Rev. 2014, 94, 1077-1098. [CrossRef] [PubMed]

102. Pekny, M.; Levéen, P.; Pekna, M.; Eliasson, C.; Berthold, C.H.; Westermark, B.; Betsholtz, C. Mice lacking glial fibrillary acidic protein display astrocytes devoid of intermediate filaments but develop and reproduce normally. EMBO J. 1995, 14, 1590-1598. [CrossRef] [PubMed]

103. Li, L.; Lundkvist, A.; Andersson, D.; Wilhelmsson, U.; Nagai, N.; Pardo, A.C.; Nodin, C.; Ståhlberg, A.; Aprico, K.; Larsson, K.; et al. Protective role of reactive astrocytes in brain ischemia. J. Cereb. Blood Flow Metab. 2008, 28, 468-481. [CrossRef] [PubMed]

104. Xu, K.; Malouf, A.T.; Messing, A.; Silver, J. Glial fibrillary acidic protein is necessary for mature astrocytes to react to $\beta$-amyloid. Glia 1999, 25, 390-403. [CrossRef]

105. Liedtke, W.; Edelmann, W.; Chiu, F.C.; Kucherlapati, R.; Raine, C.S. Experimental autoimmune encephalomyelitis in mice lacking glial fibrillary acidic protein is characterized by a more severe clinical course and an infiltrative central nervous system lesion. Am. J. Pathol. 1998, 152, 251-259.

106. Stenzel, W.; Soltek, S.; Schlüter, D.; Deckert, M. The intermediate filament GFAP is important for the control of experimental murine Staphylococcus aureus-induced brain abscess and Toxoplasma encephalitis. J. Neuropathol. Exp. Neurol. 2004, 63, 631-640. [CrossRef] 
107. Lendahl, U.; Zimmerman, L.B.; McKay, R.D. CNS stem cells express a new class of intermediate filament protein. Cell 1990, 60, 585-595. [CrossRef]

108. Frederiksen, K.; McKay, R.D. Proliferation and differentiation of rat neuroepithelial precursor cells in vivo. J. Neurosci. 1988, 8, 1144-1151. [CrossRef]

109. Dahlstrand, J.; Lardelli, M.; Lendahl, U. Nestin mRNA expression correlates with the central nervous system progenitor cell state in many, but not all, regions of developing central nervous system. Brain Res. Dev. Brain Res. 1995, 84, 109-129. [CrossRef]

110. Arai, H.; Ikota, H.; Sugawara, K.; Nobusawa, S.; Hirato, J.; Nakazato, Y. Nestin expression in brain tumors: Its utility for pathological diagnosis and correlation with the prognosis of high-grade gliomas. Brain Tumor Pathol. 2012, 29, 160-167. [CrossRef]

111. Dahlstrand, J.; Collins, V.P.; Lendahl, U. Expression of the class VI intermediate filament nestin in human central nervous system tumors. Cancer Res. 1992, 52, 5334-5341.

112. Tohyama, T.; Lee, V.M.; Rorke, L.B.; Marvin, M.; McKay, R.D.; Trojanowski, J.Q. Nestin expression in embryonic human neuroepithelium and in human neuroepithelial tumor cells. Lab. Investig. 1992, 66, 303-313. [PubMed]

113. Shimizu, T.; Sugawara, K.; Tosaka, M.; Imai, H.; Hoya, K.; Takeuchi, T.; Sasaki, T.; Saito, N. Nestin expression in vascular malformations: A novel marker for proliferative endothelium. Neurol. Med. Chir. 2006, 46, 111-117. [CrossRef] [PubMed]

114. Pallari, H.M.; Lindqvist, J.; Torvaldson, E.; Ferraris, S.E.; He, T.; Sahlgren, C.; Eriksson, J.E. Nestin as a regulator of Cdk5 in differentiating myoblasts. Mol. Biol. Cell 2011, 22, 1539-1549. [CrossRef] [PubMed]

115. Takamori, Y.; Mori, T.; Wakabayashi, T.; Nagasaka, Y.; Matsuzaki, T.; Yamada, H. Nestin-positive microglia in adult rat cerebral cortex. Brain Res. 2009, 1270, 10-18. [CrossRef] [PubMed]

116. Zerlin, M.; Levison, S.W.; Goldman, J.E. Early patterns of migration, morphogenesis, and intermediate filament expression of subventricular zone cells in the postnatal rat forebrain. J. Neurosci. 1995, 15, 7238-7249. [CrossRef]

117. Middeldorp, J.; Kamphuis, W.; Sluijs, J.A.; Achoui, D.; Leenaars, C.H.; Feenstra, M.G.; van Tijn, P.; Fischer, D.F.; Berkers, C.; Ovaa, H.; et al. Intermediate filament transcription in astrocytes is repressed by proteasome inhibition. FASEB J. 2009, 23, 2710-2726. [CrossRef]

118. Frisén, J.; Johansson, C.B.; Török, C.; Risling, M.; Lendahl, U. Rapid, widespread, and longlasting induction of nestin contributes to the generation of glial scar tissue after CNS injury. J. Cell Biol. 1995, 131, 453-464. [CrossRef]

119. Clarke, S.R.; Shetty, A.K.; Bradley, J.L.; Turner, D.A. Reactive astrocytes express the embryonic intermediate neurofilament nestin. Neuroreport 1994, 5, 1885-1888. [CrossRef]

120. Bellin, R.M.; Sernett, S.W.; Becker, B.; Ip, W.; Huiatt, T.W.; Robson, R.M. Molecular characteristics and interactions of the intermediate filament protein synemin. Interactions with alpha-actinin may anchor synemin-containing heterofilaments. J. Biol. Chem. 1999, 274, 29493-29499. [CrossRef]

121. Steinert, P.M.; Chou, Y.H.; Prahlad, V.; Parry, D.A.; Marekov, L.N.; Wu, K.C.; Jang, S.I.; Goldman, R.D. A high molecular weight intermediate filament-associated protein in BHK-21 cells is nestin, a type VI intermediate filament protein. Limited co-assembly in vitro to form heteropolymers with type III vimentin and type IV alpha-internexin. J. Biol. Chem. 1999, 274, 9881-9890. [CrossRef]

122. Moeton, M.; Stassen, O.M.; Sluijs, J.A.; van der Meer, V.W.; Kluivers, L.J.; van Hoorn, H.; Schmidt, T.; Reits, E.A.; van Strien, M.E.; Hol, E.M. GFAP isoforms control intermediate filament network dynamics, cell morphology, and focal adhesions. Cell. Mol. Life Sci. 2016, 73, 4101-4120. [CrossRef]

123. Herrmann, H.; Häner, M.; Brettel, M.; Müller, S.A.; Goldie, K.N.; Fedtke, B.; Lustig, A.; Franke, W.W.; Aebi, U. Structure and assembly properties of the intermediate filament protein vimentin: The role of its head, rod and tail domains. J. Mol. Biol. 1996, 264, 933-953. [CrossRef]

124. Hatzfeld, M.; Burba, M. Function of type I and type II keratin head domains: Their role in dimer, tetramer and filament formation. J. Cell Sci. 1994, 107 Pt 7, 1959-1972.

125. Herrmann, H.; Aebi, U. Intermediate filaments and their associates: Multi-talented structural elements specifying cytoarchitecture and cytodynamics. Curr. Opin. Cell Biol. 2000, 12, 79-90. [CrossRef]

126. Herrmann, H.; Aebi, U. Intermediate filaments: Molecular structure, assembly mechanism, and integration into functionally distinct intracellular Scaffolds. Annu. Rev. Biochem. 2004, 73, 749-789. [CrossRef] 
127. Bernal, A.; Arranz, L. Nestin-expressing progenitor cells: Function, identity and therapeutic implications. Cell. Mol. Life Sci. 2018, 75, 2177-2195. [CrossRef]

128. Hemmati-Brivanlou, A.; Mann, R.W.; Harland, R.M. A protein expressed in the growth cones of embryonic vertebrate neurons defines a new class of intermediate filament protein. Neuron 1992, 9, 417-428. [CrossRef]

129. Napier, A.; Yuan, A.; Cole, G.J. Characterization of the chicken transitin gene reveals a strong relationship to the nestin intermediate filament class. J. Mol. Neurosci. 1999, 12, 11-22. [CrossRef]

130. Guérette, D.; Khan, P.A.; Savard, P.E.; Vincent, M. Molecular evolution of type VI intermediate filament proteins. BMC Evol. Biol. 2007, 7, 164. [CrossRef]

131. Thomsen, R.; Pallesen, J.; Daugaard, T.F.; Børglum, A.D.; Nielsen, A.L. Genome wide assessment of mRNA in astrocyte protrusions by direct RNA sequencing reveals mRNA localization for the intermediate filament protein nestin. Glia 2013, 61, 1922-1937. [CrossRef]

132. de Pablo, Y.; Chen, M.; Möllerström, E.; Pekna, M.; Pekny, M. Drugs targeting intermediate filaments can improve neurosupportive properties of astrocytes. Brain Res. Bull. 2018, 136, 130-138. [CrossRef]

133. Bigas, A.; Espinosa, L. The multiple usages of Notch signaling in development, cell differentiation and cancer. Curr. Opin. Cell Biol. 2018, 55, 1-7. [CrossRef]

134. Irvin, D.K.; Zurcher, S.D.; Nguyen, T.; Weinmaster, G.; Kornblum, H.I. Expression patterns of Notch1, Notch2, and Notch 3 suggest multiple functional roles for the Notch-DSL signaling system during brain development. J. Comp. Neurol. 2001, 436, 167-181. [CrossRef]

135. Marumo, T.; Takagi, Y.; Muraki, K.; Hashimoto, N.; Miyamoto, S.; Tanigaki, K. Notch signaling regulates nucleocytoplasmic Olig2 translocation in reactive astrocytes differentiation after ischemic stroke. Neurosci. Res. 2013, 75, 204-209. [CrossRef]

136. Benner, E.J.; Luciano, D.; Jo, R.; Abdi, K.; Paez-Gonzalez, P.; Sheng, H.; Warner, D.S.; Liu, C.; Eroglu, C.; Kuo, C.T. Protective astrogenesis from the SVZ niche after injury is controlled by Notch modulator Thbs4. Nature 2013, 497, 369-373. [CrossRef]

137. Lasič, E.; Trkov Bobnar, S.; Wilhelmsson, U.; de Pablo, Y.; Pekny, M.; Zorec, R.; Stenovec, M. Nestin affects fusion pore dynamics in mouse astrocytes. Acta Physiol. (Oxf.) 2020, 228, e13399. [CrossRef]

138. Wilhelmsson, U.; Faiz, M.; de Pablo, Y.; Sjöqvist, M.; Andersson, D.; Widestrand, A.; Potokar, M.; Stenovec, M.; Smith, P.L.; Shinjyo, N.; et al. Astrocytes negatively regulate neurogenesis through the Jagged1-mediated Notch pathway. Stem Cells 2012, 30, 2320-2329. [CrossRef]

139. Wilhelmsson, U.; Kalm, M.; Pekna, M.; Pekny, M. Nestin null mice show improved reversal place learning. Neurochem. Res. 2020, 45, 215-220. [CrossRef]

140. Chou, Y.H.; Khuon, S.; Herrmann, H.; Goldman, R.D. Nestin promotes the phosphorylation-dependent disassembly of vimentin intermediate filaments during mitosis. Mol. Biol. Cell 2003, 14, 1468-1478. [CrossRef]

141. Leduc, C.; Etienne-Manneville, S. Regulation of microtubule-associated motors drives intermediate filament network polarization. J. Cell Biol. 2017, 216, 1689-1703. [CrossRef] [PubMed]

142. Sakamoto, Y.; Boëda, B.; Etienne-Manneville, S. APC binds intermediate filaments and is required for their reorganization during cell migration. J. Cell Biol. 2013, 200, 249-258. [CrossRef] [PubMed]

143. Xue, Z.G.; Cheraud, Y.; Brocheriou, V.; Izmiryan, A.; Titeux, M.; Paulin, D.; Li, Z. The mouse synemin gene encodes three intermediate filament proteins generated by alternative exon usage and different open reading frames. Exp. Cell Res. 2004, 298, 431-444. [CrossRef]

144. Izmiryan, A.; Cheraud, Y.; Khanamiryan, L.; Leterrier, J.F.; Federici, T.; Peltekian, E.; Moura-Neto, V.; Paulin, D.; Li, Z.; Xue, Z.G. Different expression of synemin isoforms in glia and neurons during nervous system development. Glia 2006, 54, 204-213. [CrossRef]

145. Hirako, Y.; Yamakawa, H.; Tsujimura, Y.; Nishizawa, Y.; Okumura, M.; Usukura, J.; Matsumoto, H.; Jackson, K.W.; Owaribe, K.; Ohara, O. Characterization of mammalian synemin, an intermediate filament protein present in all four classes of muscle cells and some neuroglial cells: Co-localization and interaction with type III intermediate filament proteins and keratins. Cell Tissue Res. 2003, 313, 195-207. [CrossRef] [PubMed]

146. Luna, G.; Lewis, G.P.; Banna, C.D.; Skalli, O.; Fisher, S.K. Expression profiles of nestin and synemin in reactive astrocytes and Müller cells following retinal injury: A comparison with glial fibrillar acidic protein and vimentin. Mol. Vis. 2010, 16, 2511-2523. [PubMed] 
147. de Souza Martins, S.C.; Agbulut, O.; Diguet, N.; Larcher, J.C.; Paulsen, B.S.; Rehen, S.K.; Moura-Neto, V.; Paulin, D.; Li, Z.; Xue, Z. Dynamic expression of synemin isoforms in mouse embryonic stem cells and neural derivatives. BMC Cell Biol. 2011, 12, 51. [CrossRef] [PubMed]

148. Bellin, R.M.; Huiatt, T.W.; Critchley, D.R.; Robson, R.M. Synemin may function to directly link muscle cell intermediate filaments to both myofibrillar Z-lines and costameres. J. Biol. Chem. 2001, 276, 32330-32337. [CrossRef]

149. Fawcett, D.W. On the occurrence of a fibrous lamina on the inner aspect of the nuclear envelope in certain cells of vertebrates. Am. J. Anat. 1966, 119, 129-145. [CrossRef]

150. Herrmann, H.; Strelkov, S.V. History and phylogeny of intermediate filaments: Now in insects. BMC Biol. 2011, 9, 16. [CrossRef]

151. de Leeuw, R.; Gruenbaum, Y.; Medalia, O. Nuclear Lamins: Thin Filaments with Major Functions. Trends Cell Biol. 2018, 28, 34-45. [CrossRef] [PubMed]

152. Dechat, T.; Adam, S.A.; Taimen, P.; Shimi, T.; Goldman, R.D. Nuclear lamins. Cold Spring Harbor Perspect. Biol. 2010, 2, a000547. [CrossRef] [PubMed]

153. Aaronson, R.P.; Blobel, G. Isolation of nuclear pore complexes in association with a lamina. Proc. Natl. Acad. Sci. USA 1975, 72, 1007-1011. [CrossRef]

154. Gerace, L.; Blobel, G. The nuclear envelope lamina is reversibly depolymerized during mitosis. Cell 1980, 19, 277-287. [CrossRef]

155. Goldman, A.E.; Maul, G.; Steinert, P.M.; Yang, H.Y.; Goldman, R.D. Keratin-like proteins that coisolate with intermediate filaments of BHK-21 cells are nuclear lamins. Proc. Natl. Acad. Sci. USA 1986, 83, 3839-3843. [CrossRef]

156. McKeon, F.D.; Kirschner, M.W.; Caput, D. Homologies in both primary and secondary structure between nuclear envelope and intermediate filament proteins. Nature 1986, 319, 463-468. [CrossRef]

157. Gray, E.G.; Guillery, R.W. On nuclear structure in the ventral nerve cord of the leech Hirudo medicinalis. Zellforsch. Mikrosk. Anat. 1963, 59, 738-745. [CrossRef]

158. Krohne, G.; Benavente, R. The nuclear lamins. A multigene family of proteins in evolution and differentiation. Exp. Cell Res. 1986, 162, 1-10. [CrossRef]

159. Worman, H.J.; Lazaridis, I.; Georgatos, S.D. Nuclear lamina heterogeneity in mammalian cells. Differential expression of the major lamins and variations in lamin B phosphorylation. J. Biol. Chem. 1988, 263, 12135-12141.

160. Toesca, A. Distribution and developmental expression of lamin-like immunoreactivity in the central nervous system. Cell Biol. Int. Rep. 1992, 16, 165-174. [CrossRef]

161. Röber, R.A.; Weber, K.; Osborn, M. Differential timing of nuclear lamin A/C expression in the various organs of the mouse embryo and the young animal: A developmental study. Development 1989, 105, 365-378. [PubMed]

162. Altman, J.; Das, G.D. Autoradiographic and histological studies of postnatal neurogenesis. I. A longitudinal investigation of the kinetics, migration and transformation of cells incorporating tritiated thymidine in neonate rats, with special reference to postnatal neurogenesis in some brain regions. J. Comp. Neurol. 1966, 126, 337-389. [CrossRef] [PubMed]

163. Mahajani, S.; Giacomini, C.; Marinaro, F.; De Pietri Tonelli, D.; Contestabile, A.; Gasparini, L. Lamin B1 levels modulate differentiation into neurons during embryonic corticogenesis. Sci. Rep. 2017, 7, 4897. [CrossRef]

164. Jung, H.J.; Coffinier, C.; Choe, Y.; Beigneux, A.P.; Davies, B.S.; Yang, S.H.; Barnes, R.H.; Hong, J.; Sun, T.; Pleasure, S.J.; et al. Regulation of prelamin A but not lamin C by miR-9, a brain-specific microRNA. Proc. Natl. Acad. Sci. USA 2012, 109, E423-E431. [CrossRef]

165. Takamori, Y.; Hirahara, Y.; Wakabayashi, T.; Mori, T.; Koike, T.; Kataoka, Y.; Tamura, Y.; Kurebayashi, S.; Kurokawa, K.; Yamada, H. Differential expression of nuclear lamin subtypes in the neural cells of the adult rat cerebral cortex. IBRO Rep. 2018, 5, 99-109. [CrossRef]

166. Dubińska-Magiera, M.; Kozioł, K.; Machowska, M.; Piekarowicz, K.; Filipczak, D.; Rzepecki, R. Emerin is required for proper nucleus reassembly after mitosis: Implications for new pathogenetic mechanisms for laminopathies detected in EDMD1 patients. Cells 2019, 8, 240. [CrossRef]

167. Peric-Hupkes, D.; Meuleman, W.; Pagie, L.; Bruggeman, S.W.; Solovei, I.; Brugman, W.; Gräf, S.; Flicek, P.; Kerkhoven, R.M.; van Lohuizen, M.; et al. Molecular maps of the reorganization of genome-nuclear lamina interactions during differentiation. Mol. Cell 2010, 38, 603-613. [CrossRef] 
168. Crisp, M.; Liu, Q.; Roux, K.; Rattner, J.B.; Shanahan, C.; Burke, B.; Stahl, P.D.; Hodzic, D. Coupling of the nucleus and cytoplasm: Role of the LINC complex. J. Cell Biol. 2006, 172, 41-53. [CrossRef]

169. Tzur, Y.B.; Wilson, K.L.; Gruenbaum, Y. SUN-domain proteins: 'Velcro' that links the nucleoskeleton to the cytoskeleton. Nat. Rev. Mol. Cell Biol. 2006, 7, 782-788. [CrossRef]

170. Bione, S.; Maestrini, E.; Rivella, S.; Mancini, M.; Regis, S.; Romeo, G.; Toniolo, D. Identification of a novel $\mathrm{X}$-linked gene responsible for Emery-Dreifuss muscular dystrophy. Nat. Genet. 1994, 8, 323-327. [CrossRef]

171. Bonne, G.; Di Barletta, M.R.; Varnous, S.; Bécane, H.M.; Hammouda, E.H.; Merlini, L.; Muntoni, F.; Greenberg, C.R.; Gary, F.; Urtizberea, J.A.; et al. Mutations in the gene encoding lamin A/C cause autosomal dominant Emery-Dreifuss muscular dystrophy. Nat. Genet. 1999, 21, 285-288. [CrossRef] [PubMed]

172. Deal, S.L.; Yamamoto, S. Unweaving the role of nuclear Lamins in neural circuit integrity. Cell Stress 2018, 2, 219-224. [CrossRef] [PubMed]

173. Schreiber, K.H.; Kennedy, B.K. When lamins go bad: Nuclear structure and disease. Cell 2013, 152, $1365-1375$. [CrossRef] [PubMed]

174. De Sandre-Giovannoli, A.; Chaouch, M.; Kozlov, S.; Vallat, J.M.; Tazir, M.; Kassouri, N.; Szepetowski, P.; Hammadouche, T.; Vandenberghe, A.; Stewart, C.L.; et al. Homozygous defects in LMNA, encoding lamin A/C nuclear-envelope proteins, cause autosomal recessive axonal neuropathy in human (Charcot-Marie-Tooth disorder type 2) and mouse. Am. J. Hum. Genet. 2002, 70, 726-736. [CrossRef] [PubMed]

175. Sullivan, T.; Escalante-Alcalde, D.; Bhatt, H.; Anver, M.; Bhat, N.; Nagashima, K.; Stewart, C.L.; Burke, B. Loss of A-type lamin expression compromises nuclear envelope integrity leading to muscular dystrophy. J. Cell Biol. 1999, 147, 913-920. [CrossRef]

176. Arocena, D.G.; Iwahashi, C.K.; Won, N.; Beilina, A.; Ludwig, A.L.; Tassone, F.; Schwartz, P.H.; Hagerman, P.J. Induction of inclusion formation and disruption of lamin $\mathrm{A} / \mathrm{C}$ structure by premutation CGG-repeat RNA in human cultured neural cells. Hum. Mol. Genet. 2005, 14, 3661-3671. [CrossRef]

177. Hagerman, R.J.; Hagerman, P. Fragile X-associated tremor/ataxia syndrome-Features, mechanisms and management. Nat. Rev. Neurol. 2016, 12, 403-412. [CrossRef]

178. Iwahashi, C.K.; Yasui, D.H.; An, H.J.; Greco, C.M.; Tassone, F.; Nannen, K.; Babineau, B.; Lebrilla, C.B.; Hagerman, R.J.; Hagerman, P.J. Protein composition of the intranuclear inclusions of FXTAS. Brain 2006, 129, 256-271. [CrossRef]

179. Hagerman, R.J.; Coffey, S.M.; Maselli, R.; Soontarapornchai, K.; Brunberg, J.A.; Leehey, M.A.; Zhang, L.; Gane, L.W.; Fenton-Farrell, G.; Tassone, F.; et al. Neuropathy as a presenting feature in fragile X-associated tremor/ataxia syndrome. Am. J. Med. Genet. A 2007, 143A, 2256-2260. [CrossRef]

180. Naidoo, M.; Anthony, K. Dystrophin Dp71 and the neuropathophysiology of Duchenne muscular dystrophy. Mol. Neurobiol. 2020, 57, 1748-1767. [CrossRef]

181. Ruggieri, S.; De Giorgis, M.; Annese, T.; Tamma, R.; Notarangelo, A.; Marzullo, A.; Senetta, R.; Cassoni, P.; Notarangelo, M.; Ribatti, D.; et al. Dp71 Expression in Human Glioblastoma. Int. J. Mol. Sci. 2019, 20, 5429. [CrossRef]

182. Ratner, N.; Miller, S.J. A RASopathy gene commonly mutated in cancer: The neurofibromatosis type 1 tumour suppressor. Nat. Rev. Cancer 2015, 15, 290-301. [CrossRef]

183. Pamenter, M.E.; Perkins, G.A.; McGinness, A.K.; Gu, X.Q.; Ellisman, M.H.; Haddad, G.G. Autophagy and apoptosis are differentially induced in neurons and astrocytes treated with an in vitro mimic of the ischemic penumbra. PLoS ONE 2012, 7, e51469. [CrossRef] [PubMed]

184. Bigley, T.M.; Reitsma, J.M.; Terhune, S.S. Antagonistic Relationship between Human Cytomegalovirus pUL27 and pUL97 Activities during Infection. J. Virol. 2015, 89, 10230-10246. [CrossRef] [PubMed]

185. Trias, E.; Beilby, P.R.; Kovacs, M.; Ibarburu, S.; Varela, V.; Barreto-Núñez, R.; Bradford, S.C.; Beckman, J.S.; Barbeito, L. Emergence of Microglia Bearing Senescence Markers During Paralysis Progression in a Rat Model of Inherited ALS. Front. Aging Neurosci. 2019, 11, 42. [CrossRef] [PubMed]

186. Ruhrberg, C.; Watt, F.M. The plakin family: Versatile organizers of cytoskeletal architecture. Curr. Opin. Genet. Dev. 1997, 7, 392-397. [CrossRef]

187. Jefferson, J.J.; Leung, C.L.; Liem, R.K. Plakins: Goliaths that link cell junctions and the cytoskeleton. Nat. Rev. Mol. Cell Biol. 2004, 5, 542-553. [CrossRef]

188. Byers, T.J.; Beggs, A.H.; McNally, E.M.; Kunkel, L.M. Novel actin crosslinker superfamily member identified by a two step degenerate PCR procedure. FEBS Lett. 1995, 368, 500-504. [CrossRef] 
189. Okuda, T.; Matsuda, S.; Nakatsugawa, S.; Ichigotani, Y.; Iwahashi, N.; Takahashi, M.; Ishigaki, T.; Hamaguchi, M. Molecular cloning of macrophin, a human homologue of Drosophila kakapo with a close structural similarity to plectin and dystrophin. Biochem. Biophys. Res. Commun. 1999, 264, 568-574. [CrossRef]

190. Sun, Y.; Zhang, J.; Kraeft, S.K.; Auclair, D.; Chang, M.S.; Liu, Y.; Sutherland, R.; Salgia, R.; Griffin, J.D.; Ferland, L.H.; et al. Molecular cloning and characterization of human trabeculin-alpha, a giant protein defining a new family of actin-binding proteins. J. Biol. Chem. 1999, 274, 33522-33530. [CrossRef]

191. Sonnenberg, A.; Liem, R.K. Plakins in development and disease. Exp. Cell Res. 2007, 313, $2189-2203$. [CrossRef] [PubMed]

192. Errante, L.D.; Wiche, G.; Shaw, G. Distribution of plectin, an intermediate filament-associated protein, in the adult rat central nervous system. J. Neurosci. Res. 1994, 37, 515-528. [CrossRef] [PubMed]

193. Kálmán, M.; Szabó, A. Plectin immunopositivity appears in the astrocytes in the white matter but not in the gray matter after stab wounds. Brain Res. 2000, 857, 291-294. [CrossRef]

194. Matsunaga, T.; Kanzaki, J.; Hosoda, Y. Ultrastructure of astrocytes in the transitional region of the human eighth cranial nerve. Hear. Res. 1994, 76, 118-126. [CrossRef]

195. Wegiel, J.; Wisniewski, H.M. Rosenthal fibers, eosinophilic inclusions, and anchorage densities with desmosome-like structures in astrocytes in Alzheimer's disease. Acta Neuropathol. 1994, 87, 355-361. [CrossRef]

196. Dubash, A.D.; Green, K.J. Desmosomes. Curr. Biol. 2011, 21, R529-R531. [CrossRef]

197. Walko, G.; Castanon, M.J.; Wiche, G. Molecular architecture and function of the hemidesmosome. Cell Tissue Res. 2015, 360, 529-544. [CrossRef]

198. Wagner, S.; Tagaya, M.; Koziol, J.A.; Quaranta, V.; del Zoppo, G.J. Rapid disruption of an astrocyte interaction with the extracellular matrix mediated by integrin alpha 6 beta 4 during focal cerebral ischemia/reperfusion. Stroke 1997, 28, 858-865. [CrossRef]

199. Mueller, S.; Klaus-Kovtun, V.; Stanley, J.R. A 230-kD basic protein is the major bullous pemphigoid antigen. J. Investig. Dermatol. 1989, 92, 33-38. [CrossRef]

200. Curry, N.; Ghezali, G.; Kaminski Schierle, G.S.; Rouach, N.; Kaminski, C.F. Correlative STED and Atomic Force Microscopy on Live Astrocytes Reveals Plasticity of Cytoskeletal Structure and Membrane Physical Properties during Polarized Migration. Front. Cell. Neurosci. 2017, 11, 104. [CrossRef]

201. Moffat, J.J.; Ka, M.; Jung, E.M.; Smith, A.L.; Kim, W.Y. The role of MACF1 in nervous system development and maintenance. Semin. Cell Dev. Biol. 2017, 69, 9-17. [CrossRef]

202. Afghani, N.; Mehta, T.; Wang, J.; Tang, N.; Skalli, O.; Quick, Q.A. Microtubule actin cross-linking factor 1, a novel target in glioblastoma. Int. J. Oncol. 2017, 50, 310-316. [CrossRef] [PubMed]

203. Pytela, R.; Wiche, G. High molecular weight polypeptides $(270,000-340,000)$ from cultured cells are related to hog brain microtubule-associated proteins but copurify with intermediate filaments. Proc. Natl. Acad. Sci. USA 1980, 77, 4808-4812. [CrossRef] [PubMed]

204. Fuchs, P.; Zörer, M.; Reipert, S.; Rezniczek, G.A.; Propst, F.; Walko, G.; Fischer, I.; Bauer, J.; Leschnik, M.W.; Lüscher, B.; et al. Targeted inactivation of a developmentally regulated neural plectin isoform (plectin 1c) in mice leads to reduced motor nerve conduction velocity. J. Biol. Chem. 2009, 284, 26502-26509. [CrossRef]

205. Castañón, M.J.; Walko, G.; Winter, L.; Wiche, G. Plectin-intermediate filament partnership in skin, skeletal muscle, and peripheral nerve. Histochem. Cell Biol. 2013, 140, 33-53. [CrossRef] [PubMed]

206. Wiche, G.; Krepler, R.; Artlieb, U.; Pytela, R.; Denk, H. Occurrence and immunolocalization of plectin in tissues. J. Cell Biol. 1983, 97, 887-901. [CrossRef]

207. Winter, L.; Wiche, G. The many faces of plectin and plectinopathies: Pathology and mechanisms. Acta Neuropathol. 2013, 125, 77-93. [CrossRef]

208. Fuchs, P.; Zörer, M.; Rezniczek, G.A.; Spazierer, D.; Oehler, S.; Castañón, M.J.; Hauptmann, R.; Wiche, G. Unusual $5^{\prime}$ transcript complexity of plectin isoforms: Novel tissue-specific exons modulate actin binding activity. Hum. Mol. Genet. 1999, 8, 2461-2472. [CrossRef]

209. Elliott, C.E.; Becker, B.; Oehler, S.; Castanon, M.J.; Hauptmann, R.; Wiche, G. Plectin transcript diversity: Identification and tissue distribution of variants with distinct first coding exons and rodless isoforms. Genomics 1997, 42, 115-125. [CrossRef]

210. Sevcik, J.; Urbanikova, L.; Kost'an, J.; Janda, L.; Wiche, G. Actin-binding domain of mouse plectin. Crystal structure and binding to vimentin. Eur. J. Biochem. 2004, 271, 1873-1884. [CrossRef] 
211. Foisner, R.; Traub, P.; Wiche, G. Protein kinase A- and protein kinase C-regulated interaction of plectin with lamin B and vimentin. Proc. Natl. Acad. Sci. USA 1991, 88, 3812-3816. [CrossRef] [PubMed]

212. Herrmann, H.; Wiche, G. Specific in situ phosphorylation of plectin in detergent-resistant cytoskeletons from cultured Chinese hamster ovary cells. J. Biol. Chem. 1983, 258, 14610-14618. [PubMed]

213. Andrä, K.; Nikolic, B.; Stöcher, M.; Drenckhahn, D.; Wiche, G. Not just scaffolding: Plectin regulates actin dynamics in cultured cells. Genes Dev. 1998, 12, 3442-3451. [CrossRef] [PubMed]

214. Anton-Lamprecht, I. Genetically induced abnormalities of epidermal differentiation and ultrastructure in ichthyoses and epidermolyses: Pathogenesis, heterogeneity, fetal manifestation, and prenatal diagnosis. J. Investig. Dermatol. 1983, 81, 149s-156s. [CrossRef]

215. Fuchs, E. Intermediate filaments and disease: Mutations that cripple cell strength. J. Cell Biol. 1994, 125, 511-516. [CrossRef]

216. Gostyńska, K.B.; Nijenhuis, M.; Lemmink, H.; Pas, H.H.; Pasmooij, A.M.; Lang, K.K.; Castañón, M.J.; Wiche, G.; Jonkman, M.F. Mutation in exon 1a of PLEC, leading to disruption of plectin isoform 1a, causes autosomal-recessive skin-only epidermolysis bullosa simplex. Hum. Mol. Genet. 2015, 24, 3155-3162. [CrossRef]

217. Winter, L.; Türk, M.; Harter, P.N.; Mittelbronn, M.; Kornblum, C.; Norwood, F.; Jungbluth, H.; Thiel, C.T.; Schlötzer-Schrehardt, U.; Schröder, R. Downstream effects of plectin mutations in epidermolysis bullosa simplex with muscular dystrophy. Acta Neuropathol. Commun. 2016, 4, 44. [CrossRef]

218. Valencia, R.G.; Walko, G.; Janda, L.; Novacek, J.; Mihailovska, E.; Reipert, S.; Andrä-Marobela, K.; Wiche, G. Intermediate filament-associated cytolinker plectin 1c destabilizes microtubules in keratinocytes. Mol. Biol. Cell 2013, 24, 768-784. [CrossRef]

(C) 2020 by the authors. Licensee MDPI, Basel, Switzerland. This article is an open access article distributed under the terms and conditions of the Creative Commons Attribution (CC BY) license (http://creativecommons.org/licenses/by/4.0/). 